\title{
The roles of metallothioneins in carcinogenesis
}

\author{
Manfei Si and Jinghe Lang*
}

\begin{abstract}
Metallothioneins (MTs) are small cysteine-rich proteins that play important roles in metal homeostasis and protection against heavy metal toxicity, DNA damage, and oxidative stress. In humans, MTs have four main isoforms (MT1, MT2, MT3, and MT4) that are encoded by genes located on chromosome 16q13. MT1 comprises eight known functional (sub)isoforms (MT1A, MT1B, MT1E, MT1F, MT1G, MT1H, MT1M, and MT1X). Emerging evidence shows that MTs play a pivotal role in tumor formation, progression, and drug resistance. However, the expression of MTs is not universal in all human tumors and may depend on the type and differentiation status of tumors, as well as other environmental stimuli or gene mutations. More importantly, the differential expression of particular MT isoforms can be utilized for tumor diagnosis and therapy. This review summarizes the recent knowledge on the functions and mechanisms of MTs in carcinogenesis and describes the differential expression and regulation of MT isoforms in various malignant tumors. The roles of MTs in tumor growth, differentiation, angiogenesis, metastasis, microenvironment remodeling, immune escape, and drug resistance are also discussed. Finally, this review highlights the potential of MTs as biomarkers for cancer diagnosis and prognosis and introduces some current applications of targeting MT isoforms in cancer therapy. The knowledge on the MTs may provide new insights for treating cancer and bring hope for the elimination of cancer.
\end{abstract}

Keywords: Metallothionein, Metal homeostasis, Cancer, Carcinogenesis, Biomarker

\section{Background}

Metallothioneins (MTs) are a family of low molecular weight (ranging from 6 to $7 \mathrm{kDa}$ ), cysteine-rich cytosolic proteins that play a vital role in metal ion homeostasis and detoxification [1, 2]. MT was first isolated by Margoshes and Vallee from horse kidney cortex as a low molecular weight protein containing cadmium in 1957 [3]. MTs are involved in metalloregulatory processes by binding to heavy metals through the thiol group of their cysteine residues. MTs have a high affinity for heavy metals, which means that they can bind to xenobiotic heavy metals to provide protection against metal toxicity, especially cadmium toxicity [4]. When MTs bind to physiological heavy metals, such as zinc and copper, they can participate in regulating cell growth and proliferation and protecting the body against oxidative stress [5]. Recently, many studies have shown that MT expression varies in different tumors, suggesting that MTs may play a vital role in carcinogenesis

\footnotetext{
* Correspondence: langjh@hotmail.com

Department of Obstetrics and Gynecology, Peking Union Medical College Hospital, Peking Union Medical College, Chinese Academy of Medical Sciences, No. 1 Shuaifuyuan, Dongcheng District, Beijing 100730, China
}

[6-10]. The elucidation of possible functions and mechanisms of MTs in tumor progression may provide potential promising markers for cancer. This review was conducted to summarize the latest data on the role of MTs in carcinogenesis and to provide diagnostic or therapeutic information to help oncologists in their clinical decision-making.

\section{Structure and classification}

MTs are highly conserved, low molecular weight proteins that are present in a broad range of taxonomic groups and display a high level of sequence heterogeneity, which results in varying molecular weights and number and distribution of cysteine residues $[1,11]$. Mammalian MTs constitute a superfamily of nonenzymatic polypeptides of 61-68 amino acids, characterized by high cysteine content (30\%), lack of aromatic amino acids, and few or no histidine residues but with abundant thiol groups to bind to heavy metals $[9,11,12]$.

In humans, MTs are encoded by a family of genes located on chromosome 16q13 and include at least 11 functional members: MT1 (MT1A, MT1B, MT1E, MT1F, MT1G, 
MT1H, MT1M, and MT1X; MT1C, MT1D, MT1I, MT1J, and MT1L are pseudogenes that cannot encode MT proteins), MT2 (also known as MT2A), MT3, and MT4 $[13,14]$. A summary of MT genes, isoforms, and location is shown in Table 1.

\section{Roles of MTs in cancer}

The well-known biological functions of MTs are related to their high affinity for heavy metals. MTs can control cellular homeostasis of zinc/copper, which is essential for cell proliferation and differentiation, and act as antioxidants to protect cells against free radicals and oxidative stress generated by mutagens, antineoplastic drugs, and radiation $[15,16]$. MTs can also bind to cadmium, mercury, platinum, or other similar heavy metals to protect cells and tissues against heavy metal toxicity [4]. In addition, MTs play a protective role against DNA damage and apoptosis [17-19]. Accumulating evidence indicates that MTs play important roles in carcinogenesis and cancer therapy. MTs participate in the process of carcinogenesis and play critical roles in tumor growth, progression, metastasis, and drug resistance (Fig. 1). To provide a comprehensive insight into the complicated relation between MTs and cancer, we summarized the dysregulated expression and functions of MT isoforms in various tumor tissues in Table 2.

\section{Expression of MT isoforms in various types of cancers}

Numerous studies have demonstrated that changes in MT expression are associated with the process of carcinogenesis and cancer progression. However, the expression of MTs is not universal in all human cancers. Previous studies have shown that MT expression is upregulated in breast cancer, nasopharyngeal cancer, ovarian cancer, urinary bladder cancer, and melanoma [20-24], while in other cancers, such as hepatocellular carcinoma, prostate cancer, and papillary thyroid carcinoma, MT expression is downregulated $[7,25,26]$. Theocharis et al. also observed that among lung cancer subtypes, MT expression was prominent in squamous cell lung carcinoma and adenocarcinoma but absent in small cell lung cancer [27]. The differential expression of MTs depends on the type and differentiation status of tumors, as well as other environmental stimuli and/or gene mutations [17, 28, 29]. Nevertheless, a better understanding of the changes in the expression of particular MT isoforms in various cancers can help identify specific therapeutic targets and reverse tumor progression.

In humans, MTs have four main isoforms: MT1, MT2, MT3, and MT4. Of these four isoforms, MT1 and MT2 are ubiquitously expressed in various tissues, while MT3 and MT4 are minor isoforms with restricted expression in specialized cells and tissues, such as the brain, reproductive organs, and stratified squamous epithelium [7, 17]. MT3 was first purified and characterized as a growth inhibitory factor (GIF) in the human brain [30] and was later designated as a third member of the MT family [31]. MT4 was discovered in the stratified squamous epithelium in the skin, esophagus, and tongue [32]. Furthermore, MT1 and MT2 are basally expressed and highly induced by a variety of stimuli including metals, hormones, cytokines, growth factors, oxidants, stress, and irradiation, while MT3 and MT4 are constitutively expressed despite signal changes in vitro or in vivo [33].

Krizkova et al. have provided a comprehensive summary of the expression and regulation of individual MT isoforms in various types of malignancies [34]. In Fig. 2, the transcript levels of MT isoforms in cancers are compared with those in normal samples by using Oncomine databases (threshold setting: $p$ value, 0.01 ; fold change, 2; gene rank, top 10\%). The figure shows that the mRNA levels of MT isoforms are significantly up/downregulated in various types of cancers (Fig. 2). These data clearly indicate that MT isoforms can be targeted to treat cancer and

Table 1 Genetic information related to functional MT isoforms obtained from the National Center of Biotechnology Information (NCBI)

\begin{tabular}{|c|c|c|c|c|}
\hline MT isoforms & Gene ID & Location & GenBank accession number & References \\
\hline MT1A & 4489 & Chromosome 16, NC_000016.10 (56638666..56640087) & NM_005946.2 & {$[170,171]$} \\
\hline MT1B & 4490 & Chromosome 16, NC_000016.10 (56651899..56653204) & NM_005947.2 & {$[172,173]$} \\
\hline MT1E & 4493 & Chromosome 16, NC_000016.10 (56625673..56627112) & NM_175617.3 & {$[143,172]$} \\
\hline MT1F & 4494 & Chromosome 16, NC_000016.10 (56657943..56659303) & NM_005949.3 & {$[131,174]$} \\
\hline MT1G & 4495 & Chromosome 16, NC_000016.10 (56666735..56668065, complement) & NM_005950.2 & {$[172,175]$} \\
\hline MT1H & 4496 & Chromosome 16, NC_000016.10 (56669814..56671129) & NM_005951.2 & {$[8,176]$} \\
\hline MT1M & 4499 & Chromosome 16, NC_000016.10 (56632622..56633986) & NM_176870.2 & {$[142,172]$} \\
\hline MT1X & 4501 & Chromosome 16, NC_000016.10 (56682470..56684196) & NM_005952.3 & {$[176,177]$} \\
\hline MT2A & 4502 & Chromosome 16, NC_000016.10 (56608566..56609497) & NM_005953.4 & {$[178,179]$} \\
\hline MT3 & 4504 & Chromosome 16, NC_000016.10 (56589355..56591088) & NM_005954.3 & {$[31,180]$} \\
\hline MT4 & 84560 & Chromosome 16, NC_000016.10 (56565049..56568957) & NM_032935.2 & {$[32,181]$} \\
\hline
\end{tabular}


Drug resistance

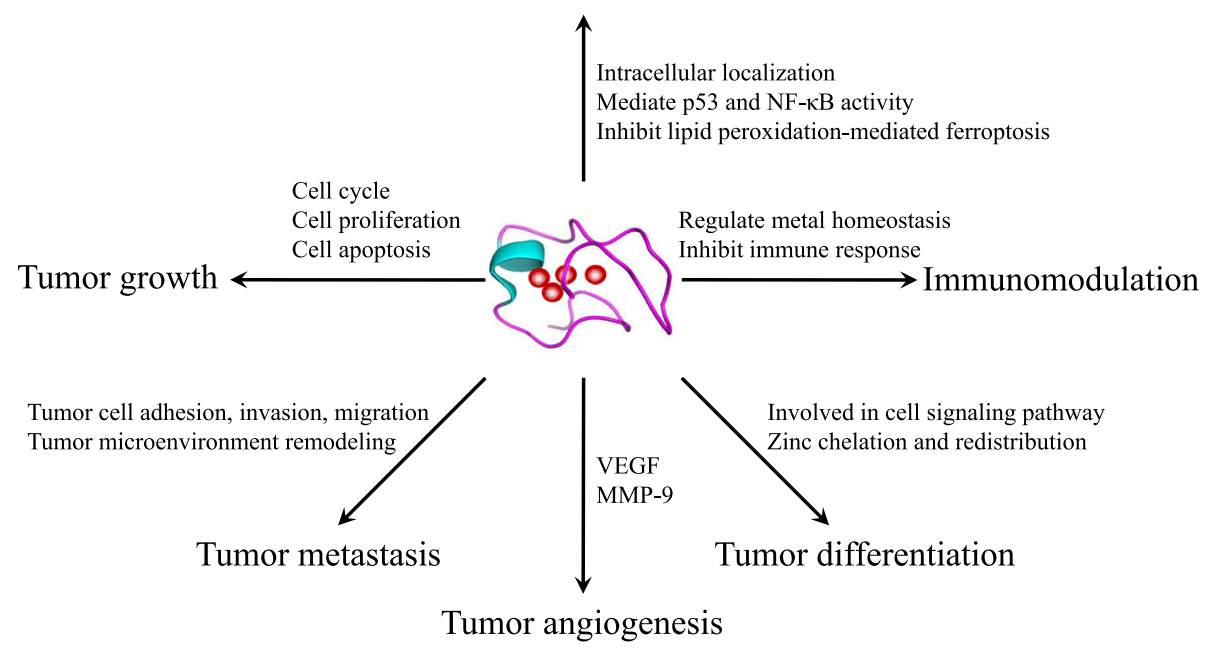

Fig. 1 Roles of MTs in carcinogenesis

enhance the efficiency of anticancer therapy due to their important roles and altered expression in various cancers. Therefore, knowledge on the expression of MT isoforms could be fully utilized for tumor diagnosis and anticancer therapy.

\section{Tumorigenesis}

Tumorigenesis, also called carcinogenesis or oncogenesis, refers to the formation of a tumor in which normal cells are transformed into cancer cells. Any changes at the cellular, genetic, and epigenetic levels that disrupt the balance between proliferation and programmed cell death, in the form of apoptosis, such as DNA mutations and epimutations, can contribute to the development of cancer. MTs have been shown to play an important role in carcinogenesis. To better understand the roles of MTs in cancer, the National Cancer Institute held a workshop that focused on three topics: the role of zinc in tumor cell pathobiology, the role of MTs in metal carcinogenesis, and the role of MTs in tumor cells and potential in cancer chemotherapy [35]. Since then, a large number of studies have been conducted to investigate the roles of MTs in carcinogenesis.

\section{Tumor growth}

The tumor growth-promoting effects of MTs involve the following potential mechanisms. Nagel et al. demonstrated that cytoplasmic MTs reached a maximum level during the G1/S cell cycle transition, a period when cells prepare for DNA synthesis, thereby demonstrating a physiological role of MTs in tumor cell proliferation [36]. Studies have shown that zinc is required for G1/S phase transition [37, 38]. Thus, it can be hypothesized that MTs regulate the supply of zinc for proteins and the activity of zinc-dependent transcription factors to modulate tumor cell growth and proliferation. Later, Lim et al. observed that the downregulation of MT2A expression in breast cancer cells could induce cell cycle arrest at the G1 phase to inhibit cancer cell growth, and the underlying molecular mechanisms involved the regulation of cell cycle-related genes including ataxia telangiectasia mutated (ATM) and cell division cycle 25A (cdc25A) [39].

MTs also participate in cell proliferation. Ki-67 is one of the most sensitive markers of cell proliferation. Werynska and colleagues have shown a positive correlation between the expression of MT1/2 and that of the proliferation markers Ki-67 and minichromosome maintenance protein 2 (MCM-2) in non-small cell lung cancer [40]. A similar positive correlation between MTs and Ki-67 expression had also been confirmed in breast cancer [20, 41], nasopharyngeal carcinoma [21], large intestine adenocarcinoma [42], basal cell carcinoma [43], and soft tissue sarcomas such as malignant fibrous histiocytoma, liposarcoma, and synovial sarcoma [44].

MTs have also been shown to inhibit apoptosis [19]. MTs can act as zinc donors for transcription factors such as hypoxia-inducible factor- $1 \alpha$ (HIF- $1 \alpha)$ and tumor suppressors such as P53 to influence cell growth $[17,45]$. P53 is a zinc-binding transcription factor that can inhibit cell cycle progression and induce apoptosis in response to DNA damage. MTs can remove zinc ions from P53 protein molecules, thus leading to the changes in the spatial structure of P53, leading to its inactivation and thus result in uncontrolled cell proliferation $[20,46]$. Moreover, MTs have been demonstrated to interact with nuclear factor $-\mathrm{kB}$ (NF-kB) and mediate its antiapoptotic effects [47], probably because zinc is an essential component for the 
Table 2 Overview of the dysregulated expression and functions of MT isoforms in cancer

\begin{tabular}{|c|c|c|c|c|}
\hline Cancer type & MT isoforms & Expression & Functions & References \\
\hline $\begin{array}{l}\text { Acute } \\
\text { nonlymphoblastic leukemia }\end{array}$ & MT & Positive & Resistance-related proteins & [182] \\
\hline \multirow[t]{2}{*}{ Acute myeloid leukemia } & MT1G, MT1A & Positive & Inversely correlated with PU.1 expression & [183] \\
\hline & MT3 & Down & Promoter hypermethylation & [154] \\
\hline $\begin{array}{l}\text { Adenoid cystic carcinomas } \\
\text { of the salivary glands }\end{array}$ & MT & Up & Myoepithelial differentiation & [184] \\
\hline \multirow[t]{4}{*}{ Basal cell carcinoma } & MT & Up & Infiltrative growth & [185] \\
\hline & MT1, MT2 & Up & Promote proliferation: Ki-67 antigen expression & [43] \\
\hline & MT3 & Down & Possibly based on DNA methylation & [186] \\
\hline & MT3 & $\begin{array}{l}\text { Low to moderate } \\
\text { expression }\end{array}$ & Carcinogenesis & [187] \\
\hline \multirow[t]{5}{*}{ Bladder carcinoma } & MT & Up & Drug resistance & [188] \\
\hline & MT2 & Up & Cisplatin resistance & [99] \\
\hline & MT3 & Up & Carcinogenesis and increase tumor grade & [189] \\
\hline & MT1X & Up & Correlated with tumor grade & [190] \\
\hline & MT & Up & Poor survival and cisplatin resistance & [23] \\
\hline \multirow[t]{6}{*}{ Breast cancer } & MT3 & Up & Poor prognosis & [130] \\
\hline & MT2A & Up & Increase invasiveness & [191] \\
\hline & MT1E & $\begin{array}{l}\text { Present in estrogen } \\
\text { receptor (ER)-negative } \\
\text { breast cancer }\end{array}$ & Myoepithelial differentiation and tumor invasiveness & [191] \\
\hline & MT2A & Up & $\begin{array}{l}\text { Modulate cell cycle via the ATM/Chk2/cdc25A } \\
\text { signaling pathway }\end{array}$ & [39] \\
\hline & MT2A & Up & $\begin{array}{l}\text { Upregulation of matrix metalloproteinase (MMP)- } 9 \text {; } \\
\text { enhance cell invasion and migration }\end{array}$ & {$[82]$} \\
\hline & MT3 & Up & Increase invasiveness & [83] \\
\hline Cholangiocarcinoma & MT & Partly positive & Poor prognosis & [128] \\
\hline \multirow[t]{3}{*}{ Colonic cancer } & MT & Up & Promote proliferation & {$[36]$} \\
\hline & MT1F & Down & Loss of heterozygosity & {$[52]$} \\
\hline & MT1G, MT1X, MT2A & Down & $\begin{array}{l}\text { Associated with the depth of tumor invasion, lymph } \\
\text { node metastasis, and tumor stage }\end{array}$ & {$[52]$} \\
\hline \multirow[t]{4}{*}{ Colorectal cancer } & $\begin{array}{l}\text { MT2A, MT1B, MT1F, } \\
\text { MT1G, MT1H, MT1B, } \\
\text { MT1F, MT1G, MT1H, } \\
\text { MT2A }\end{array}$ & Down & Poor clinical outcome & [192] \\
\hline & $\begin{array}{l}\text { MT1E, MT1F, MT1G, } \\
\text { MT1H, MT1M, } \\
\text { MT1X MT2A }\end{array}$ & Down & Epigenetic mechanisms & {$[6]$} \\
\hline & MT2A & Up & $\begin{array}{l}\text { Interact with Fas-associated death domain (FADD) } \\
\text { in NF-kB pathway to promote cell proliferation }\end{array}$ & [49] \\
\hline & MT1G & Down & Colorectal cancer cell differentiation & {$[67]$} \\
\hline \multirow[t]{6}{*}{ Ductal breast cancer } & MT1E & $\begin{array}{l}\text { High in ER-negative } \\
\text { cancer tissues }\end{array}$ & Mediate effector genes downstream of ER & [193] \\
\hline & MT1F & Up & Influence histological differentiation & {$[58]$} \\
\hline & MT2A & Up & Cell proliferation & [41] \\
\hline & MT2A & Up & Chemoresistance (doxorubicin) & [59] \\
\hline & MT1, MT2 & Up & Increased proliferative potential & [20] \\
\hline & MT3 & Down & Epigenetic changes & {$[88]$} \\
\hline Endometrial carcinoma & MT1, MT2 & Up & Modify p53 expression & [141] \\
\hline
\end{tabular}


Table 2 Overview of the dysregulated expression and functions of MT isoforms in cancer (Continued)

\begin{tabular}{|c|c|c|c|c|}
\hline Cancer type & MT isoforms & Expression & Functions & References \\
\hline & MT1E & Down & Promoter hypermethylation & [143] \\
\hline $\begin{array}{l}\text { Esophageal } \\
\text { adenocarcinoma }\end{array}$ & MT3 & Down & DNA methylation & [152] \\
\hline \multirow{5}{*}{$\begin{array}{l}\text { Esophageal squamous } \\
\text { cell carcinoma }\end{array}$} & MT & Up & Chemoresistance to cisplatin; poor prognosis & [194] \\
\hline & MT3 & Down & DNA methylation & [153] \\
\hline & MT1G & Down & Gene methylation & [145] \\
\hline & MT1G & Down & Promoter hypermethylation & [146] \\
\hline & MT1M & Down & DNA methylation; correlated with smoking duration & [195] \\
\hline Gallbladder carcinoma & MT & Up & Histological dedifferentiation & [63] \\
\hline \multirow[t]{8}{*}{ Gastric carcinoma } & MT3 & Down & Hypermethylation & [151] \\
\hline & MT1G & Up & Cisplatin resistance & [196] \\
\hline & MT1X & Up & Irinotecan resistance & [103] \\
\hline & MT & Up & Poor survival and high recurrence rate & [81] \\
\hline & MT2A & Down & Inhibit the activation of the NF-KB pathway & [135] \\
\hline & MT2A & Down & Be a potential target of miR-23a & [197] \\
\hline & MT1D (MTM) & Down & Enhance migration and invasion & [198] \\
\hline & MT1M, MT1JP & Down & $\begin{array}{l}\text { Associated with tumor diameter, differentiation, lymphatic } \\
\text { metastasis, distal metastasis, invasion, and tumor node } \\
\text { metastasis (TNM) stage }\end{array}$ & [199] \\
\hline Glioma & MT1E & $\begin{array}{l}\text { In proportion } \\
\text { to the motility } \\
\text { of glioma cell }\end{array}$ & $\begin{array}{l}\text { Enhance tumor proliferation, invasion, and migration } \\
\text { through regulation of activation and expression of MMPs }\end{array}$ & {$[84,85]$} \\
\hline Hepatoblastoma & MT1G & Down & Promoter hypermethylation & [147] \\
\hline \multirow[t]{12}{*}{ Hepatocellular carcinoma } & MT1F & Down & Cell growth & [200] \\
\hline & MT1G & Down & Allelic loss on chromosome 16q12.1-q23.1 & [155] \\
\hline & MT1, MT2A & Down & $\begin{array}{l}\text { Transcriptional repression: dephosphorylation of the } \\
\text { transcription factor CCAAT/enhancer-binding protein } \\
\text { (C/EBP) a through phosphatidylinositol 3-kinase } \\
\text { (PI3K)/AKT signaling pathway }\end{array}$ & [25] \\
\hline & MT1X, MT2A & Down & $\begin{array}{l}\text { Malignant transformation of hepatocytes; local invasion; } \\
\text { hepatitis B virus infection }\end{array}$ & [201] \\
\hline & MT1G & Down & Tumor suppressor gene; promoter hypermethylation & [148] \\
\hline & MT1M & Down & Increase NF-kB activity & [142] \\
\hline & MT1, MT2 & Down & $\begin{array}{l}\text { Promoter hypermethylation and transcriptional repression; } \\
\text { prognostic marker }\end{array}$ & [133] \\
\hline & MT1M, MT1G & Down & Promoter methylation & [136] \\
\hline & MT1M & Down & Poor prognosis & [134] \\
\hline & MT1, MT2 & Down & Associated with the disruption of circadian clock genes & [202] \\
\hline & MT1H & Down & Regulate the Wnt/ß-catenin signaling pathway & [8] \\
\hline & MT1M & Down & Inhibit tumorigenesis & [203] \\
\hline $\begin{array}{l}\text { Intrahepatic } \\
\text { cholangiocarcinoma }\end{array}$ & $\begin{array}{l}\text { MT1A, MT1E, MT1F, } \\
\text { MT1G, MT1H, } \\
\text { MT1IP, MT1X }\end{array}$ & Down & Hypermethylation & [204] \\
\hline Lung cancer & $\begin{array}{l}\text { MT1A, MT2A, MT1E, } \\
\text { MT1G }\end{array}$ & Down & Gene methylation & [205] \\
\hline Large cell lung cancer & $\begin{array}{l}\text { MT1F, MT1G, } \\
\text { MT1M, MT1X }\end{array}$ & Up & Poor prognosis & {$[206]$} \\
\hline \multirow[t]{2}{*}{ Melanoma } & MT & Up & Poor prognosis & {$[24,125]$} \\
\hline & MT1E & Down & DNA methylation & [144] \\
\hline
\end{tabular}


Table 2 Overview of the dysregulated expression and functions of MT isoforms in cancer (Continued)

\begin{tabular}{|c|c|c|c|c|}
\hline Cancer type & MT isoforms & Expression & Functions & References \\
\hline & MT1, MT2 & Up & $\begin{array}{l}\text { Intratumoural macrophage infiltration to defect } \\
\text { host immune response and metastasis formation }\end{array}$ & [77] \\
\hline Nasopharyngeal cancer & MT & Up & Cell proliferation & [21] \\
\hline \multirow[t]{7}{*}{ Non-small cell lung cancer } & MT & Up & Tumor cell proliferation and short survival & [122] \\
\hline & MT1H & Up & Drug resistance (cisplatin) & [207] \\
\hline & MT1, MT2 & Up & $\begin{array}{l}\text { Promote proliferation: expressions of Ki- } 67 \text { and } \\
\text { minichromosome maintenance protein-2 (MCM-2) } \\
\text { (positive correlation) }\end{array}$ & {$[40]$} \\
\hline & MT3 & Up & Pathogenesis & [208] \\
\hline & $\begin{array}{l}\text { MT1B, MT1F, MT1G, } \\
\text { MT1H, MT1X }\end{array}$ & Up & Pathogenesis & [131] \\
\hline & MT1F, MT2A & Up & Poor outcome & [131] \\
\hline & MT1E & Down & Cell differentiation & [131] \\
\hline \multirow{4}{*}{$\begin{array}{l}\text { Oral squamous cell } \\
\text { carcinoma }\end{array}$} & MT & Up & Poor prognosis & {$[127]$} \\
\hline & $\begin{array}{l}\text { MT1A, MT1X, MT3, } \\
\text { MT4 }\end{array}$ & Down & Possible markers for oral carcinogenesis & [209] \\
\hline & MT1G & Down & Poor survival & [209] \\
\hline & MT1F & Up & Associated with tobacco use & [209] \\
\hline Osteosarcoma & $\begin{array}{l}\text { MT1E, MT1H, MT1X, } \\
\text { MT2A, MT1B, MT1G, } \\
\text { MT1L }\end{array}$ & Up & Drug resistance & [210] \\
\hline \multirow[t]{3}{*}{ Ovarian cancer } & MT1, MT2 & Up & Mutant p53; histological grade & [22] \\
\hline & MT2A & Up & Inhibit cell death & [211] \\
\hline & MT1L, MT1X, MT2A & Up & Low malignant potential or early cancer onset & [212] \\
\hline Pancreatic carcinoma & MT & Partly positive & $\begin{array}{l}\text { Metastasis, poor prognosis, and poor histological } \\
\text { grade }\end{array}$ & [62] \\
\hline \multirow{3}{*}{$\begin{array}{l}\text { Papillary thyroid } \\
\text { carcinoma }\end{array}$} & MT1G & Down & Promoter hypermethylation & [149] \\
\hline & $\begin{array}{l}\text { MT1E, MT1G, MT1X, } \\
\text { MT2A }\end{array}$ & Down & Promoter methylation and transcriptional repression & [7] \\
\hline & MT1G & Down & $\begin{array}{l}\text { Modulate the activity of the PI3K/AKT and Rb/E2F } \\
\text { pathways }\end{array}$ & [89] \\
\hline \multirow[t]{10}{*}{ Prostate cancer } & MT3 & $\begin{array}{l}\text { Highly variable } \\
\text { increase }\end{array}$ & Control prostate epithelial cell growth & [213] \\
\hline & MT1X & Down & Advanced prostate cancer & [214] \\
\hline & MT2A & Up & Inhibit cell death & [211] \\
\hline & MT3 & Up & Inhibit cell growth and increase drug resistance & [53] \\
\hline & MT1G & Down & Promoter hypermethylation & [150] \\
\hline & MT1F, MT1M & Down & Associated with perineural invasion & [215] \\
\hline & MT1H & Down & $\begin{array}{l}\text { Enhance the histone methyltransferase activity of } \\
\text { euchromatin histone methyltransferase } 1 \text { (EHMT1) }\end{array}$ & [26] \\
\hline & MT2A & Down & $\begin{array}{l}\text { Single nucleotide polymorphism (SNP); metal } \\
\text { accumulation }\end{array}$ & [14] \\
\hline & MT3 & $\begin{array}{l}\text { Depend on } \\
\text { cell type }\end{array}$ & $\begin{array}{l}\text { Increase cell proliferation, invasion, and tumorigenic } \\
\text { activities }\end{array}$ & [104] \\
\hline & MT1E & Down & DNA methylation & [10] \\
\hline \multirow[t]{4}{*}{ Renal cell cancer } & MT & Up & Tumor grade & [64] \\
\hline & MT2A & Up & Stimulate cellular proliferation & [216] \\
\hline & MT1A, MT1G & Down & Growth arrest and induction of apoptosis & [216] \\
\hline & MT1A, MT1E, MT1G, & Down & Tumorigenesis & {$[217]$} \\
\hline
\end{tabular}


Table 2 Overview of the dysregulated expression and functions of MT isoforms in cancer (Continued)

\begin{tabular}{|c|c|c|c|c|}
\hline Cancer type & MT isoforms & Expression & Functions & References \\
\hline & \multicolumn{4}{|l|}{ MT1H, MT1L } \\
\hline & MT1H, MT1G, MT2A & Down & Promoter methylation & [45] \\
\hline $\begin{array}{l}\text { Salivary gland } \\
\text { adenocarcinoma }\end{array}$ & MT & Up & $\begin{array}{l}\text { High immunoreactivity and microenvironment } \\
\text { remodeling }\end{array}$ & [90] \\
\hline Serous ovarian cancer & MT & Up & Diagnosis of malignancy and worse prognosis & [218] \\
\hline Small cell lung cancer & MT & $45 \%$ positive & P53 expression and short-term survival & [121] \\
\hline \multirow[t]{2}{*}{ Soft tissue sarcoma } & MT & Up & $\begin{array}{l}\text { Ki-67 expression, grade of malignancy, and prognostic } \\
\text { appraisal }\end{array}$ & [44] \\
\hline & $\begin{array}{l}\text { MT2A, MT1X, MT1F, } \\
\text { MT1H }\end{array}$ & Up & Metastasis & [219] \\
\hline \multirow{2}{*}{$\begin{array}{l}\text { Squamous cell } \\
\text { carcinoma of the } \\
\text { tongue }\end{array}$} & MT & Positive & Delay cells entering apoptosis & [220] \\
\hline & MT & Positive & $\begin{array}{l}\text { Correlated with depth of invasion, vascular invasion, and } \\
\text { lymph node metastasis }\end{array}$ & [221] \\
\hline \multirow[t]{2}{*}{ Testicular cancer } & MT & Up & Chemoresistance & [222] \\
\hline & MT & Up & Early diagnosis & [115] \\
\hline $\begin{array}{l}\text { Transitional cell } \\
\text { carcinoma of the } \\
\text { bladder }\end{array}$ & MT & Up & Poor survival & [126] \\
\hline
\end{tabular}

\begin{tabular}{|c|c|c|c|c|c|c|c|c|c|c|c|c|c|c|c|c|c|c|c|c|c|}
\hline \multirow{2}{*}{$\begin{array}{r}\text { Analysis Type by Cancer } \\
\text { Bladder Cancer }\end{array}$} & \multicolumn{2}{|c|}{$\begin{array}{l}\text { Cancer } \\
\text { vs. } \\
\text { Normal } \\
\text { MTIA }\end{array}$} & \multicolumn{2}{|c|}{$\begin{array}{c}\text { Cancer } \\
\text { vs. } \\
\text { Normal } \\
\text { MTIB }\end{array}$} & \multicolumn{2}{|c|}{$\begin{array}{l}\text { Cancer } \\
\text { vs. } \\
\text { Normal } \\
\text { MTIE }\end{array}$} & \multicolumn{2}{|c|}{$\begin{array}{c}\text { Cancer } \\
\text { vs. } \\
\text { Normal } \\
\text { MTIF }\end{array}$} & \multicolumn{2}{|c|}{$\begin{array}{c}\text { Cancer } \\
\text { vs. } \\
\text { Normal } \\
\text { MTIG }\end{array}$} & \multicolumn{2}{|c|}{$\begin{array}{c}\text { Cancer } \\
\text { vs. } \\
\text { Normal } \\
\text { MTIH }\end{array}$} & \multicolumn{2}{|c|}{$\begin{array}{c}\text { Cancer } \\
\text { vs. } \\
\text { Normal } \\
\text { MTIM }\end{array}$} & \multicolumn{2}{|c|}{$\begin{array}{c}\text { Cancer } \\
\text { vs. } \\
\text { Normal } \\
\text { MTIX } \\
\end{array}$} & \multicolumn{2}{|c|}{$\begin{array}{c}\text { Cancer } \\
\text { vs. } \\
\text { Normal } \\
\text { MT2A } \\
\end{array}$} & \multicolumn{2}{|c|}{$\begin{array}{c}\text { Cancer } \\
\text { vs. } \\
\text { Normal } \\
\text { MT3 } \\
\end{array}$} & $\begin{array}{c}\text { Cancer } \\
\text { vs. } \\
\text { Normal } \\
\\
\text { MT4 } \\
\end{array}$ \\
\hline & & 1 & 1 & & & 1 & & 2 & & 1 & 1 & 1 & & 2 & 1 & 1 & & 2 & & & \\
\hline Brain and CNS Cancer & & 1 & 1 & & 1 & 1 & 1 & & 1 & 2 & 1 & 2 & 1 & 1 & 3 & 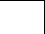 & 1 & & 1 & 6 & \\
\hline Breast Cancer & 1 & 2 & & 2 & & 6 & 1 & & 1 & 3 & & 4 & & 18 & & 15 & & 2 & & 2 & \\
\hline \multicolumn{22}{|l|}{ Cervical Cancer } \\
\hline Colorectal Cancer & & 7 & & 9 & & 20 & & 20 & & 25 & & 24 & & 21 & & 21 & & 20 & & 4 & \\
\hline Esophageal Cancer & & & & & 1 & & 1 & & & 1 & & 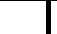 & & 1 & & 2 & & & & - & \\
\hline Gastric Cancer & & 3 & & 3 & & 7 & & 10 & & 11 & & 8 & & 10 & & 9 & & 4 & & 3 & 1 \\
\hline Head and Neck Cancer & & & & & 1 & 2 & & 3 & & 4 & & 2 & & 2 & & 3 & 1 & & & & \\
\hline Kidney Cancer & & & & & & 6 & & 9 & & 11 & & 11 & & 2 & & 6 & & 5 & & & \\
\hline Leukemia & & & & & & & 1 & 2 & 1 & 3 & 1 & 1 & & 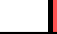 & 1 & 1 & & 2 & & & \\
\hline Liver Cancer & & & & 1 & & 5 & & 7 & & 8 & & 6 & & 6 & & 5 & & 3 & & & \\
\hline Lung Cancer & & 2 & & 4 & & 5 & & 3 & & 2 & & 3 & & 6 & & 5 & & 5 & & 2 & \\
\hline Lymphoma & 3 & & & & 4 & & 5 & & 3 & & 6 & & & & 8 & & 8 & 1 & & & \\
\hline Melanoma & & & & & & & & & & & & & & & & 2 & & & & & \\
\hline Myeloma & 1 & & & & & & & 1 & & & & & & 1 & & & & 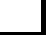 & & & \\
\hline Other Cancer & 2 & & 1 & & 4 & 1 & 6 & 1 & 5 & 1 & 5 & & 2 & & 4 & & 5 & 1 & & 1 & 1 \\
\hline Ovarian Cancer & & & & 1 & & & 2 & & 5 & & 1 & & & 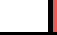 & 1 & & & 1 & & & \\
\hline Pancreatic Cancer & & & & 1 & & 2 & & 3 & & 4 & & 4 & & 1 & & 1 & & 1 & & & \\
\hline Prostate Cancer & & & & & & 3 & & 1 & & 2 & & 2 & & 4 & & 5 & & 1 & & & \\
\hline Sarcoma & & 1 & & & & 9 & & 10 & & 12 & & 9 & & 9 & & 8 & & 7 & & 3 & \\
\hline Significant Unique Analyses & 7 & 17 & 3 & 21 & 11 & 68 & 17 & 71 & 16 & 89 & 15 & 77 & 3 & 84 & 18 & 84 & 15 & 55 & 1 & 21 & 2 \\
\hline Total Unique Analyses & & 99 & 25 & & & & 44 & 41 & 44 & & 44 & & 35 & 4 & 43 & & 410 & & 410 & & 205 \\
\hline & & 1 & 5 & 10 & & 10 & 5 & 1 & & & & & & & & & & & & & \\
\hline & & Cell & lor is & deter & nined & by the & & & nk per & centil & for th & & & & & & & & & & \\
\hline $\begin{array}{l}\text { Fig. } 2 \text { Transcript levels of MT is } \\
\text { datasets with statistically signifi } \\
\text { tissues) (threshold setting: } p \text { val } \\
\text { meeting the threshold }\end{array}$ & & $\begin{array}{l}\text { in di } \\
\mathrm{mRl} \\
\text { fold }\end{array}$ & erent & type & s of & anc & & $10 \%$ & ure $w$ & las $g$ & ber $\mathrm{i}$ & $n$ the & colo & red c & ell $r$ & & $\begin{array}{l}\text { cating } \\
\text { r vs. C } \\
\text { ints th }\end{array}$ & the & nber & oro & $\begin{array}{l}\text { ff } \\
\text { lormal } \\
\text { atasets }\end{array}$ \\
\hline
\end{tabular}


DNA-binding function of NF-кB [48]. Marikar et al. revealed a new phenomenon that the interaction of the phosphorylated Fas-associated death domain (FADD) with MT2A was involved in the increase in cell proliferation and inhibition of cell apoptosis in colorectal cancer via the NF-kB pathway [49]. MT expression can protect cells from a variety of apoptotic stimuli, including oxidative stress, heavy metals, and chemotherapeutic agents (doxorubicin, etoposide, etc.) [18, 50, 51].

Intriguingly, in vitro experiments have confirmed that MT1F transfection into colon cancer cells could decrease cell proliferation and colony formation and increase cell apoptosis rates to inhibit cell growth. The authors also obtained similar results with in vivo experiments in which compared with those in empty vector-expressing mice, the tumor growth rate and average tumor size and weight were reduced in MT1F-expressing mice. These results highlighted MT1F as a tumor suppressor that can inhibit tumor growth in vivo [52]. Similarly, low expression and tumor suppressor activity of MT1H were identified in prostate cancer. In detail, the induced expression of $\mathrm{MT} 1 \mathrm{H}$ reduced the colony formation and decreased the entry of prostate cells into the $S$ and $M$ phases to suppress cell growth [26]. A similar suppressive role of MT1H was also reported in hepatocellular carcinoma [8]. Dutta et al. demonstrated that the stable transfection of PC-3 cells to overexpress the MT3 gene significantly reduced the cell growth relative to both nontransfected PC-3 cells and blank vector-transfected control cells [53].

Altogether, these findings indicate that MTs may contribute to tumor growth by regulating cell cycle arrest, cell proliferation, and apoptosis. However, whether MTs play an oncogenic or tumor-suppressive role depends on their isoforms and the type of tumors.

\section{Tumor differentiation}

Cellular differentiation is the process by which a cell changes from one type to another. The "grade" of histological differentiation or the grade of malignancy is used as a measure of cancer progression and includes the ability to form glandular structures, cellular polymorphism, and evident mitotic activity. Many studies have reported that MTs participate in cell differentiation. Aikins and fellow researchers investigated the influence of extremely low-frequency electromagnetic fields (ELFEMFs) on zinc-MT3 interactions during the neural differentiation of human bone marrow-derived mesenchymal cells. Their study found that during this interaction, MT3 expression was downregulated, and the formation of zinc-MT3 complexes was enhanced to maintain zinc homeostasis. A new homeostatic regulatory mechanism was thus discovered, which involved the zinc-MT3 complex and other MT3-interacting proteins to drive neural differentiation, thereby highlighting the potential diagnostic and clinical applications for MT3 in neurodegenerative diseases [54]. Moreover, Wu et al. demonstrated MTs as negative regulators for interleukin (IL)-27-induced type 1 regulatory $\mathrm{T}$ cell differentiation [55]. Hirako et al. uncovered that the overexpression of MT1G could inhibit the differentiation of all-trans retinoic acid (ATRA)-induced NB4 acute promyelocytic leukemia cells [56]. MT2A expression was reported to influence the osteosarcoma cell differentiation toward the osteogenic lineage. In other words, MT2A overexpression could the enhance cell differentiation [57]. Additionally, numerous studies have revealed a relationship between MT expression and tumor differentiation. Jin et al. found that the expression of MT1F and MT2A in histological grade 3 breast cancer was significantly higher than that in histological grades 1 and 2 in breast cancer [41, 58]. Similar results were recently demonstrated by other authors [20,59-61]. The relationship between MT expression and tumor histological grade was also demonstrated in pancreatic ductal carcinoma [62], gallbladder carcinoma [63], renal cancer [64], ovarian adenocarcinoma $[22,65]$, and endometrial carcinoma [66]. All of the mentioned studies demonstrated a strong positive correlation between MT expression and tumor grade, showing that MT expression was enhanced with increasing tumor grade. To investigate the role of MT1G in the differentiation of colorectal cancer cells, Arriaga et al. transfected MT1G-myc expression plasmids into H29 cells, which stably overexpress MT1G. The authors uncovered that MT1G was involved in the process of tumor cell differentiation mainly through the Notch signaling pathway and labile zinc chelation and redistribution [67].

Cell differentiation is necessary for normal development. Undifferentiated and poorly differentiated cells have a high likelihood to form tumors. As mentioned above, MTs have been reported to participate in cell differentiation and have been found to be positively correlated with histological tumor grade. These findings may provide a new approach for treating cancers in which tumor cells are prompted to differentiate into more mature cells by using MT-related pharmacological agents.

\section{Tumor angiogenesis}

The formation of new blood vessels is a required step for tumorigenesis because tumors need a network of blood vessels to obtain sufficient oxygen and essential nutrients for their growth, progression, and metastasis [68]. Several studies have demonstrated that MTs play an important role in tumor angiogenesis. Miyashita and Sato showed that MT1 was expressed in vascular endothelial cells (ECs) at the site of angiogenesis, and the downregulation of MT1 expression inECs resulted in the inhibition of cell proliferation, migration, and angiogenesis in vivo, which 
indicated that MT1 was involved in the regulation of angiogenesis [69]. Penkowa et al. observed that decreased levels of the growth factors b-fibroblast growth factor (b-FGF), transforming growth factor $\beta 1$ (TGF $\beta 1$ ), and vascular endothelial growth factor (VEGF) could mediate the reduction in angiogenesis and regeneration in MT1 +2-deficient mice after a cortical freeze injury in the central nervous system. Furthermore, the authors found that MT1+2-deficient transgenic mice expressing IL-6 displayed a dramatic reduction in IL-6-induced angiogenesis. These results suggested that $\mathrm{MT} 1+2$ participate in the angiogenic process possibly by regulating the expression of angiogenesis-promoting factors [70].

VEGF is a major contributor to angiogenic processes such as EC proliferation, migration, and sprouting. Wierzowiecka et al. carried out a study in three breast cancer cell lines, in which an increased expression of selected MT isoforms was induced by zinc ions to various degrees. The expression of VEGF was slightly increased after the stimulation with zinc ions, which suggested a correlation between MT expression and VEGF expression in breast cell lines [71]. Another study showed that MT3 could significantly induce the expression of VEGF through a HIF-1 $\alpha$-dependent mechanism in brain ECs [72]. Schuermann and colleagues also confirmed that MT2 acts upstream of VEGF expression in regulating EC proliferation, migration, and angiogenesis [73].

Matrix metallopeptidase (MMP)-9, also known as gelatinase $\mathrm{B}$, is widely associated with tumor progression because of its role in extracellular matrix (ECM) remodeling, angiogenesis, and neovascularization [74]. MMP-9 is a member of the zinc-dependent metalloproteinase family that has been demonstrated to interact with MTs [75]. Hence, it can be hypothesized that MTs participate in angiogenesis via MMP-9. Zbinden et al. identified MTs as a participant in collaterogenesis and angiogenesis and observed combined dysfunction of ECs, smooth muscle cells (SMCs), and macrophages in MT knockout (KO) mice. MMP-9, platelet-derived growth factor (PDGF) receptor, and VEGF were significantly downregulated in SMCs isolated from MT KO animals, which contributed to SMC dysfunction [76].

In conclusion, MTs can induce the upregulation of angiogenesis-related genes, such as VEGF and MMP-9; act on ECs, SMCs, and macrophages; and result in the formation of new blood vessels to promote tumor growth, progression, and metastasis (Fig. 3). Therefore, further investigation of MTs may provide therapeutic targets for inhibiting angiogenesis and tumor progression.

\section{Tumor metastasis}

Metastasis is a complex, multistep process by which cancers spread from the primary site to a secondary site within the body. MT overexpression has been demonstrated as a marker of aggressive tumor behavior in many kinds of cancers. Emri et al. showed that MT1+2 overexpression was significantly more frequent in metastatic primary cutaneous malignant melanoma $(\mathrm{CMM})(p=0.018)$, which suggested the predictive value of MT overexpression in the metastatic ability of CMM [77]. In primary colorectal cancer, MT expression was significantly associated with lymph node metastasis, suggesting that MTs may modulate the tumor metastatic process [78]. A similar result has been reported in the lymph node metastasis

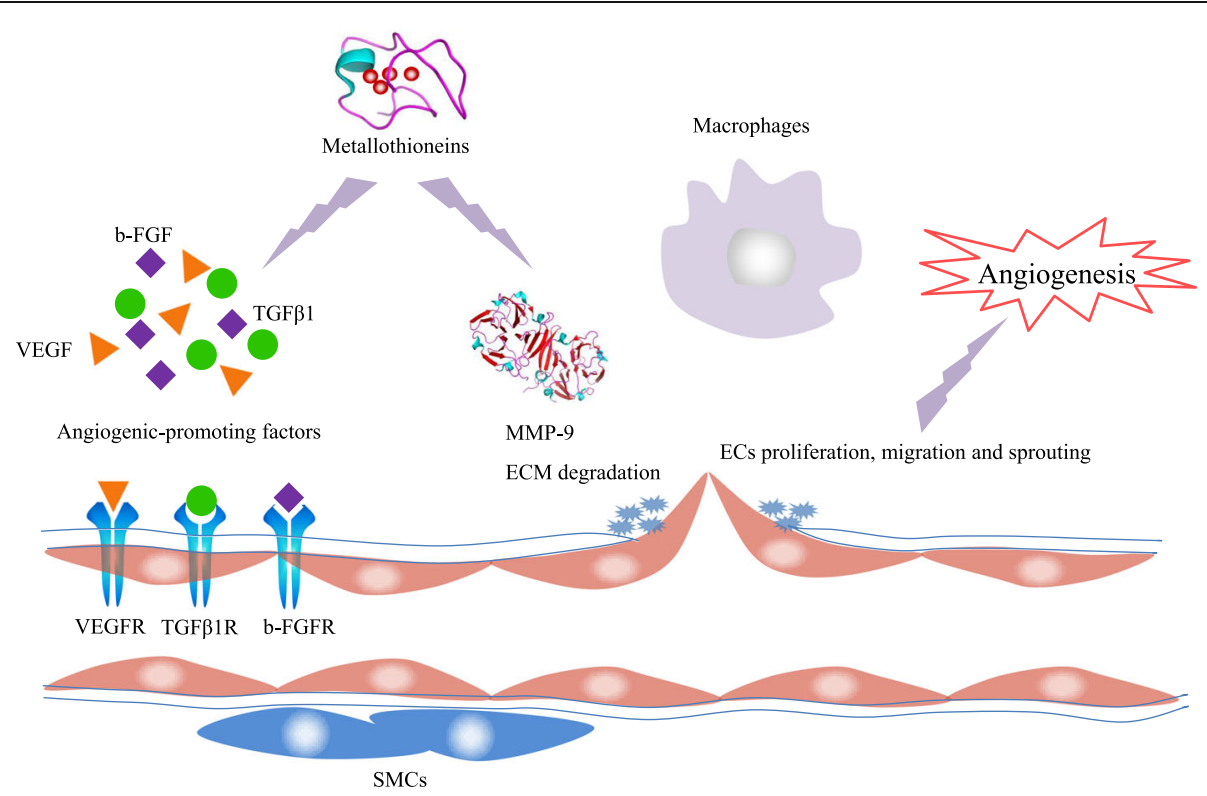

Fig. 3 Roles of MTs in tumor angiogenesis. ECM, extracellular matrix; ECs, endothelial cells; SMCs, smooth muscle cells 
of breast cancers [79]. In esophageal squamous cell carcinoma, MT expression was indicative of metastatic potential and was associated with the lymph node metastasis $(p=0.0343)$ and distant metastasis $(p=0.0452)$ [80]. In gastric cancer patients, MT overexpression was significantly correlated with lymph node and distant metastasis, as well as the number of metastatic lymph nodes [81]. Clinical studies have demonstrated that MT2A overexpression enhanced breast cancer cell invasion and migration via the upregulation of MMP-9 induced by the activation of the AP-1 and NF-kB signaling pathways [82]. In addition, studies have suggested that MT3 overexpression can increase the invasiveness of breast cancer cell by modulating MMP-3 expression [83]. Similarly, Ryu et al. verified the expression of MT1E in relation to the motility of glioma cell lines, and MT1E enhanced the invasion and migration of malignant glioma cells by modulating the activity of MMPs and NF- $\mathrm{kB} / \mathrm{p} 50[84,85]$.

Interestingly, Yan et al. conducted an in vitro study to assess the effect of MT1F expression on colon cancer cells and found that migration, invasion, and adhesion were significantly inhibited in MT1F-expressing colon cancer cells [52]. Ramaswamy et al. have shown that the downregulation of MT3 was one of the 17-gene signature associated with metastasis in primary solid tumors [86]. A decrease in MT3 expression was observed in pituitary adenocarcinoma with spinal cord metastasis [87]. Likewise, Gomulkiewicz et al. showed that the MT3 expression was significantly lower in patients with ductal breast cancer with lymph node metastasis than in patients without metastasis [88]. Furthermore, Fu et al. demonstrated a significant positive association of MT1G hypermethylation with lymph node metastasis in 178 papillary thyroid cancer patients [89].

Studies have also demonstrated that MTs are involved in tumor microenvironment remodeling to facilitate tumor spread, invasion, and metastasis [90-92].

Collectively, these data suggest that MTs contribute to tumor metastasis by enhancing the invasion and migration of tumor cells and tumor microenvironment remodeling. However, the up/downregulation of MTs depends on their isoforms and the type of tumors, as well as other environmental stimuli or gene mutations.

\section{Tumor microenvironment remodeling and immune escape}

Subramanian Vignesh and Deepe elucidated the immunomodulatory role of MTs and demonstrated MTs as an important component of the innate and adaptive immune systems regulating metal homeostasis, particularly zinc and thus impacting the immune cell redox status, enzyme function, and cell signaling [93]. Emri et al. observed that metastatic CMM cases were associated with the presence of tumor-infiltrating CD68+ $(p=0.001)$ and CD163+ $(p<0.001)$ macrophages. Furthermore, MT overexpression was found to be related to the presence of tumor-infiltrating CD68+ macrophages $(p=0.003)$. Hence, MTs might play an immunomodulatory role to contribute to melanoma progression [77]. MT expression has also been associated with the number and activity of immune cells during immune responses in breast cancer [94].

MTs can be released into the extracellular environment in response to cellular stress. Furthermore, extracellular MTs can bind to the plasma membrane of lymphocytes and influence their immunomodulatory activities [95]. MTs have been found to be able to suppress murine cytotoxic lymphocyte activity, reduce the level of detectable major histocompatibility complex class I and CD8 molecules on lymphocytes, and increase IL-2 receptor expression, indicating that MTs are involved in cell-mediated immunosuppression functions and contribute to antitumor immunity [96].

Studies have shown that MTs can inhibit immune responses and are involved in the microenvironment remodeling to control and accelerate tumor growth and initiate metastasis [90, 91]. Dutsch-Wicherek et al. observed that the immunoreactivity levels of MTs in pharyngeal squamous cell carcinoma were statistically higher than those in the reference tissues. In addition, higher MT immunoreactivity levels were detected in tumor patients with lymph node metastasis than in patients without metastasis. The authors concluded that MT expression within the tumor cells was associated with tumor aggressiveness and metastasis via microenvironment remodeling [91]. Canpolat and Lynes found that endogenous MTs are synthesized during the normal immune response or as a consequence of toxicant exposure suppressed in vivo immune function, indicating an immunomodulatory role of MTs [97]. Inhibition of the immune response by MTs may indicate that MTs are involved in the remodeling of the immunosuppressive tumor microenvironment [90].

These findings collectively suggest that MTs act as immunomodulators to interfere with the immune response and participate in tumor microenvironment remodeling to drive tumor immune evasion.

\section{Tumor drug resistance}

MTs contribute to the development of drug resistance through a variety of mechanisms in many types of cancers. A previous study has demonstrated that the overexpression of MTs was involved in the acquisition of resistance to anticancer drugs, including cis-diamminedichloroplatinum (II), chlorambucil, and melphalan [98]. Since then, the relationship between MT expression and tumor drug resistance has been examined in different tumor types.

In bladder carcinoma, an enhanced expression of MT2 was identified in the cisplatin-resistant cells, suggesting that cisplatin resistance may be partly mediated by MT2 
[99]. This result was recently corroborated by Wülfing et al. If bladder cancer cells expressed MTs, the patients treated with cisplatin chemotherapy had a significantly poor survival rate; in other words, MT overexpression may mediate resistance to cisplatin-based chemotherapy [23]. Matsumoto et al. reported an enhanced expression of MTs following chemotherapy in non-small cell lung cancer, which may be related to drug resistance [100]. Similarly, MT expression was found to be correlated with cisplatin resistance in three human small cell lung cancer lines [101]. Lee et al. confirmed that in contrast to those in cisplatin-sensitive cells, MTs were overexpressed in cisplatin-resistant mouse melanoma cancer cells. Reducible poly(oligo-D-arginine) (rPOA) was used to deliver short hairpin RNAs against MTs (shMT) into cells and resulted in the downregulation of MT expression and enhanced the anticancer effect of cisplatin. Additionally, in vivo tumor models showed synergistically enhanced the tumor-suppressive effects of co-administration of shMT/ rPOA oligopeptoplex and cisplatin. These results demonstrated that MT overexpression was at least one of the main reasons for cisplatin resistance [102]. Upregulation of MTs was shown to increase irinotecan resistance in gastric cancer patients [103]. Furthermore, MT3 overexpression increased chemotherapeutic drug resistance in PC-3 prostate cancer cells $[53,104]$.

Although several studies have investigated MT-mediated resistance mechanisms, the results still need to be further validated. Kondo et al. demonstrated that nuclear MTs were indicative of greater resistance to cisplatin than diffuse MTs in human hormone-independent prostatic cell lines, implying that the nuclear localization of MTs is important for the resistance to chemical drugs [105]. In addition, Surowiak et al. demonstrated that the nuclear expression of MTs increased during the exposure to cisplatin and was indicative of drug resistance in ovarian cancer cells [106]. Thus, nuclear MT expression probably represents a mechanism of drug resistance that protects the DNA of tumor cells from the toxic effects of chemical drugs. However, Gansukh et al. showed a divergent result in which the nuclear and cytoplasmic expression of MTs had no effect on cisplatin resistance in non-small cell lung cancer cells, perhaps because the mechanism of cisplatin resistance in this cancer is independent of MTs [107]. Arriaga et al. showed that the overexpression of the MT1G sensitized colorectal cancer cells to the chemotherapeutic agents' oxaliplatin and 5 -fluorouracil, which may have been mediated by the activation of p53 and repression of NF- $\mathrm{KB}$ activity [108]. Sun et al. also demonstrated a novel molecular mechanism of drug resistance. Specifically, they showed that enhanced MT1G expression contributed to sorafenib resistance in hepatocellular carcinoma by inhibiting lipid peroxidation-mediated ferroptosis [109]. Habel et al. showed that chemotherapy resistance induced by MT2A was partially due to zinc chelation [57]. A study by Yap et al. revealed that reduced MT2A gene expression could enhance the chemosensitivity to doxorubicin [59]. Hence, it can be speculated that inhibiting the expression of certain MT isoforms can increase the anticancer activity of drugs, thereby providing a potential therapeutic strategy.

Therefore, as a predictor of chemoresistance, MT expression might be evaluated for the selection of appropriate anticancer agents or be modulated to resensitize chemoresistant tumor cells to improve the efficacy of chemotherapy. Although MTs have an ability to increase the chemoresistance, many studies indicate that MTs can prevent cardiotoxicity induced by anticancer agents by scavenging free radicals and attenuating oxidative stress [110-112]. Hence, strategies to balance cardioprotection and chemoresistance deserve to be investigated. Heger et al. had proposed a possible solution that involved heart-specific overexpression of MTs by transient transfection to help overcome unwanted cardiotoxicity without increasing tumor chemoresistance [111]. Further studies are needed to explore the potential mechanisms of MTs, thus enhancing their cardioprotective effect while inhibiting chemoresistance.

\section{MTs as biomarkers for cancer diagnosis and prognosis}

MTs can be readily detected in patient's blood, and the level of serum MTs is positively correlated with the pathological state, disease stage, and degree of cancer progression; thus, MTs act as an enriched source of biomarkers.

Petrlova et al. had described various electroanalytical techniques to detect MTs in human serum [113]. Through electrochemical analysis, MT levels were found to be elevated in most patients with melanoma, breast, and colon cancer [114]. Tariba et al. selected 25 patients with newly diagnosed testicular germ cell tumors (TGCTs) and 22 healthy volunteers in their study and found that serum MT concentration in patients with TGCT was significantly higher than that in control individuals; additionally, in combination with the commonly used markers, MTs could improve the early diagnosis rate [115]. In another study with 46 prostate cancer patients diagnosed by biopsy, total prostate-specific antigen (tPSA) levels and MT levels were examined in serum samples. In the first cohort $(n=17)$ diagnosed with prostate cancer, tPSA levels were within the physiological range of $0-4 \mathrm{ng} / \mathrm{mL}$ for over $36.9 \%$ of cases, indicating the unreliability of tPSA as a marker of prostate cancer. However, although tPSA levels were normal in the first group, MT levels were significantly elevated $(p=0.05)$, indicating that MTs might be used as an additional prostate cancer marker to increase the reliability of prostate cancer diagnosis [116]. Krizkova et al. also demonstrated that determination of serum MT levels by differential pulse voltammetry could 
be considered as a promising diagnostic tool for childhood solid tumors [117].

Previous reports had revealed MT overexpression as a valuable prognostic marker for tumor progression and drug resistance in a wide range of cancers, such as ovarian cancer [22, 118], breast cancer [119, 120], small cell lung cancer [121], non-small cell lung cancer [122], renal cell carcinoma [123, 124], melanoma [24, 125], bladder cancer $[23,126]$, oral squamous cell carcinoma [127], and cholangiocarcinoma [128]. Surowiak et al. indicated that increased expression of MTs represented an unfavorable predictive factor in cisplatin-treated ovarian cancer patients [118]. In primary ovarian cancer, MT-positive patients had shorter survival than MT-negative patients, and this result could be explained by the positive correlation between MT expression and histological grade [22]. In primary invasive ductal breast carcinoma, MT-positive patients had a significantly poorer prognosis than MT-negative patients $(p<0.01)$, which suggested a prognostic value of MT expression [129]. Similarly, MT3 overexpression has been reported to be associated with poor prognosis in breast cancer [130]. The association of high MT expression with short-term survival had been demonstrated in small cell lung cancer [121] and non-small cell lung cancer [122], and enhanced expression of MT1F and MT2A isoforms predicted poor clinical outcomes in non-small cell lung cancer in which upregulated MT1F expression was associated with larger primary tumor size and higher grade of malignancy [131]. In a prospective study on 520 melanoma patients, MT overexpression was related to an increased risk of melanoma progression with poor prognosis and survival rate [125]. In 2006, the authors updated this study with an 11-year prospective cohort comprising 1270 melanoma patients to confirm the previous results [24]. Another study compared the predictive roles of MT overexpression with those of sentinel lymph node biopsy and found that MT overexpression was an excellent prognostic predictor of cancer progression and patient survival [132]. Additionally, a significant correlation was found between MT overexpression and poor overall survival $(p=0.0005)$, disease-specific survival $(p=0.0004), \quad$ disease-free survival $\quad(p=0.05), \quad$ and disease-free progression $(p=0.0008)$ in patients with transitional cell carcinoma of the bladder [126]. Another study also demonstrated that the overexpression of MTs $(p=$ 0.003 ) was an independent risk factor associated with poor survival in bladder cancer patients [23]. Similar results were observed in oral squamous cell carcinoma patients [127] and in cholangiocarcinoma patients suffering from either intrahepatic cholangiocarcinoma or hilar extrahepatic cholangiocarcinoma [128].

However, in other types of cancers such as prostate cancer [10], hepatocellular carcinoma [133, 134], and gastric cancer [135], the downregulation of MT expression was associated with poor prognosis. Demidenko and colleagues attempted to identify the prognostic biomarkers for predicting biochemical recurrence (BCR) of prostate cancer. They identified 455 differentially expressed genes through global gene expression profiling, among which seven genes (CHI3L2, FABP7, GHRH, GPR52, MT1E, $O L R 1$, and $S A A 2$ ) were selected for further validation in two independent prostate cancer cohorts. The results suggested that MT1E downregulation was a potential biomarker of early BCR and poor prognosis in prostate cancer patients [10]. Park and Yu demonstrated that MT1 and MT2 are important prognostic markers in hepatocellular carcinoma. The loss of nuclear expression of MT1 and MT2 was associated with high Edmondson-Steiner grade and microvascular invasion and poor prognosis indicated by recurrence-free survival $(p=0.029)$ and overall survival $(p=0.007)$ [133]. In another study, low MT1M expression was found to be linked to high alpha-fetoprotein (AFP) levels and high tumor recurrence rates following curative resection in patients with hepatocellular carcinoma [134]. In addition, combined MT1M and MT1G promoter methylation in hepatocellular carcinoma patients was associated with a high incidence of vascular invasion and lymph node or extrahepatic metastasis, thereby acting as an effective prognostic marker [136]. Decreased MT2A expression was reported to be associated with advanced TNM stages, tumor differentiation, and poor outcomes in patients with gastric cancer [135].

Taken together, these findings indicate that MTs play critical roles in almost all aspects of cancer, thereby providing opportunities for the development of MTs as novel diagnostic and prognostic biomarkers.

\section{Mechanisms involving MTs in cancer}

MTs can act as zinc donors to mediate the activity of zinc-dependent transcription factors such as P53 and NF-kB to regulate cell apoptosis and tumor cell growth. MTs can remove zinc ions from P53 protein molecules, leading to the changes in its spatial structure and loss of function, similar to p53 mutations, and resulting in uncontrolled cell proliferation. Meplan et al. demonstrated that MT overexpression exerted a potent inhibitory effect on the transcriptional activity of P53, consistent with the metal chelation effect of MTs [137]. Interaction of MTs with the tumor suppressor P53 appears to be crucial for the development and progression of tumors [46, 138, 139]. Conversely, the activation of P53 has been shown to be an important factor in the expression and induction of MTs in cancer cells [140]. Positive correlations between MT and p53 expression were found in endometrial carcinoma, implying that MTs can regulate p53 expression [141]. The study by Hengstler et al. also showed a significant correlation between MT expression and mutant p53 in ovarian carcinoma [22]. Furthermore, the antiapoptotic role of MTs 
may also be related to its modulation of NF-kB activity. Abdel-Mageed and Agrawal revealed that MTs cause the transactivation of NF-kB, which results in the inhibition of apoptosis [47]. In contrast, Sakurai et al. demonstrated MTs as a negative regulator of NF- $\mathrm{kB}$ activity by using the MT-null embryonic cell lines [48]. MT2A has been shown to regulate NF- $\mathrm{KB}$ pathway activation to participate in tumor progression in gastric cancer [135] and colorectal cancer [49]. Downregulation of MT1M can also contribute to hepatocellular carcinogenesis by increasing the activity of NF-kB [142].

Numerous studies have demonstrated that the elimination of tumor suppressor gene activity by promoter methylation is responsible for carcinogenesis, a mechanism that has been confirmed in many human cancers. Demidenko et al. revealed MT1E promoter methylation as a possible mechanism of gene inactivation, which resulted in the reduced expression of MT1E in prostate cancer [10]. Similar observations were validated in patients with endometrial carcinoma [143] and melanoma [144]. In previous studies, MT1G suppression was reported to contribute to carcinogenesis in papillary thyroid carcinoma, prostate cancer, esophageal squamous cell carcinoma, hepatocellular carcinoma, and hepatoblastoma, and the mechanism of MT1G gene silencing was related to promoter hypermethylation [145-150]. In gastric carcinoma, Deng et al. showed that the reduced expression of MT3 was due to the hypermethylation of CpG islands on intron 1 [151]. DNA methylation of MT3 was detected in esophageal adenocarcinoma, resulting in MT3 gene silencing. Moreover, DNA methylation of MT3 from -127 to -8 sites was shown to be significantly correlated with advanced tumor stages and lymph node metastasis, implying that the methylation of promoter regions may be involved in tumor progression [152]. DNA methylation of MT3 was also confirmed in esophageal squamous cell carcinoma, but there was no significant association between the MT3 methylation status and prognosis [153]. Tao et al. observed epigenetic inactivation of MT3 via promoter hypermethylation in pediatric acute myeloid leukemia, and MT3 could act as a tumor suppressor by inhibiting tumor cell proliferation and inducing apoptosis [154]. Han et al. demonstrated that MT1H acts as a tumor suppressor by interacting with euchromatin histone methyltransferase 1 (EHMT1) to increase the methyltransferase activity of EHMT1 on histone 3 [26]. Earlier studies have shown that MT1G inactivation was mediated by promoter methylation in thyroid cancer [7, 149]. Fu et al. revealed in-depth molecular mechanisms of MT1G as a tumor suppressor in thyroid carcinogenesis, which involved the inhibition of cell growth and invasion and induction of cell cycle arrest and apoptosis via the inhibition of the phosphorylation of Akt and Rb, that is, through modulation of the phosphatidylinositol 3-kinase (PI3K)/AKT and Rb/E2F signaling pathways [89].
Beyond DNA methylation, there are other potential mechanisms of MTs in carcinogenesis. The suppression of MT1 and MT2A in human hepatocellular carcinoma was related to the dephosphorylation (inactivation) of the transcription factor CCAAT/enhancer-binding protein $(\mathrm{C} /$ EBP) $\alpha$ through the PI3K/AKT signaling pathway rather than the gene hypermethylation [25]. Zheng et al. established stable hepatocellular cancer cell lines with constitutive expression of MT1H to examine the potential role of $\mathrm{MT1H}$ in hepatocellular carcinogenesis. They found that MT1H could suppress Wnt $/ \beta$-catenin signaling to inhibit tumor progression, including hepatocellular cancer cell proliferation, invasion, and migration [8]. In terms of the studies on genomic changes, Chan et al. noted that MT1G downregulation in hepatocellular carcinoma was due to the allelic loss on chromosome 16q12.1-q23.1 [155]. Additionally, Yan et al. demonstrated that the potential mechanism of MT1F downregulation in colon cancer was a loss of heterozygosity (LOH) [52]. Furthermore, Krzeslak et al. found that single nucleotide polymorphism (SNP) (rs28336003) could affect the expression of MT2A in prostate cancer and that this may be associated with metal accumulation, causing the cells to lose protection against heavy metal toxicity and carcinogenicity [14].

As described above, many potential molecular mechanisms of MTs in tumorigenesis have been reported by scholars (Table 3), but countless challenges remain to be overcome. Further studies should be conducted to fully elucidate the exact mechanisms mediating the complex roles of MTs in cancer. In addition to focusing on currently known mechanisms, we need to do a search for potential targets and ultimately provide novel strategies for cancer therapy.

\section{MTs as cancer therapeutic targets}

Given the importance of MTs in physiological and pathological processes, accumulating data have exhibited the possible role of MTs as a therapeutic molecular target against human diseases, such as neurodegenerative diseases, cerebral ischemia and retinal diseases, liver diseases, chemical- and radiation-induced carcinogenesis, pulmonary inflammation, and obesity [156-158].

MT overexpression promotes cell growth, angiogenesis, metastasis, and chemoresistance in many kinds of human tumors. Thus, MT gene $\mathrm{KO}$ is gaining interest as a therapeutic approach for the treatment of these cancers. RNA interference is widely employed as a strategy to stably inhibit gene expression. Packaging RNA (pRNA) of bacteriophage phi2 9 has been used to deliver short interfering RNA (siRNA) into the cells for gene therapy $[159,160]$. Tarapore et al. constructed pRNA/siRNA chimeras targeting MT2A in ovarian cancer cells and showed that the pRNA/siRNA complex could inhibit the expression of MT2A, resulting in a decreased cell proliferation. This 
Table 3 Roles of MTs in carcinogenesis

\begin{tabular}{lll}
\hline MT isoforms & Mechanisms & References \\
\hline MTs & Regulation of P53 activity & {$[22,46,137-139,141]$} \\
MTs & Regulation of NF-KB activity & {$[47-49,135,142]$} \\
MTs & Methylation of DNA promoters & {$[7,10,143-152,154,204]$} \\
MT1H & Increasing the methyltransferase activity of EHMT1 on histone 3 & {$[26]$} \\
MT1G & Modulation of the PI3KAKT and Rb/E2F signaling pathways & {$[89]$} \\
MT1, MT2A & Modulation of the PI3KAKT signaling pathway & {$[25]$} \\
MT1H & Suppression of the Wnt/3-catenin signaling pathway & {$[8]$} \\
MT1G & Allelic loss on chromosome 16q12.1-q23.1 & {$[155]$} \\
MT1F & Loss of heterozygosity & {$[52]$} \\
MT2A & SNP (rs28336003) & {$[14]$}
\end{tabular}

result was also confirmed in breast and prostate cancer cells [161]. Therefore, the pRNA/siMT2A chimera represents a highly potent therapeutic approach against cancer. Lai et al. reported that silencing the MT2A gene by siRNAs induced entosis (the internalization of a cell into another cell) [162] in breast cancer, and this result may provide new insights into strategies to limit tumor cell growth [163]. Similarly, Lee et al. used shMT/rPOA oligopeptoplexes to downregulate MT expression and reverse the cisplatin resistance and verified enhanced anticancer efficacy in both cisplatin-resistant cell lines and in vivo mouse cancer models [102]. Antisense approaches targeting unique mRNA molecules are intended to reduce the expression of specific proteins, and this strategy is possibly applicable for cancer therapy [164]. The downregulation of MTs by antisense approaches has been shown to induce growth inhibition in breast cancer cells [165], leukemia cells [166], and nasopharyngeal cancer [167].

Sharma et al. highlighted the clinical significance of MTs in cell therapy and nanomedicine [168]. The study and application of nanoparticles (NPs) are increasingly gaining focus in biological systems and nanomedicine. MT expression can be specifically induced by metal nanoparticles and cancer to serve as a defensive mechanism and provide protection by acting as free radical scavengers, anti-inflammatory agents, and antiapoptotic agents and by mediating zinc-dependent gene expression involved in cell apoptosis, proliferation, or differentiation $[111,168,169]$. Hence, MTs could be used as early and sensitive biomarkers to assess the effectiveness and environmental safety of newly developed NPs. Based on these properties, MT-capped semiconductor NPs are now being further developed for their theranostic applications as third-generation NPs.

MT isoforms can be targeted to treat cancer and enhance the efficacy of anticancer therapies. However, not many strategies of targeting MT isoforms have reached the clinical practice as therapeutic agents.
Further work is needed to achieve and update these technologies and to evaluate the clinical safety of these strategies modulating MT expression. Targeting particular MT isoforms in various cancer types indicates a promising future for the biomedical applications of MTs in the field of cancer treatment.

\section{Conclusions}

MTs, a unique class of metalloproteins, are emerging as important players in carcinogenesis. MTs play a pivotal role in multiple biological processes by virtue of their unusual metal-binding functions, such as participating in metal ion homeostasis and detoxification, regulating cell growth and proliferation, and protecting the body against DNA damage and oxidative stress. Moreover, currently available experimental evidence suggests vital roles of MTs in tumor growth, differentiation, angiogenesis, metastasis, immune escape, and drug resistance. However, the data on the relationship between MT expression and tumor types are variable, that is, MT expression is not universal in all human cancers not only because the functions of MTs are isoform- and tissue-specific but also because MT expression varies with different environmental stimuli or gene mutations and interactions with other cell signaling pathways or the tumor microenvironment. In addition, contradictory results in the same kind of cancer may be because some studies had only been carried out in a small number of cases. This review provides a comprehensive summary of the complicated roles of MTs in carcinogenesis. The identification of changes in the expression of particular MT isoforms can contribute to tumor diagnosis and targeted therapy. Future studies of MTs will not only reveal their functions in the pathogenesis of cancer but also provide new insights into cancer diagnosis and therapy. 


\section{Abbreviations}

AFP: Alpha-fetoprotein; ATM: Ataxia telangiectasia mutated; ATRA: All-trans retinoic acid; BCR: Biochemical recurrence; b-FGF: b-fibroblast growth factor; C/EBP: CCAAT/enhancer-binding protein; cdc25A: Cell division cycle 25A; CMM: Cutaneous malignant melanoma; ECM: Extracellular matrix; ECs: Endothelial cells; EHMT1: Euchromatin histone methyltransferase 1; ELFEMFs: Extremely low-frequency electromagnetic fields; ER: Estrogen receptor; FADD: Fas-associated death domain; GIF: Growth inhibitory factor; HIF-1a: Hypoxia-inducible factor-1a; IL: Interleukin; KO: Knockout; LOH: Loss of heterozygosity; MCM-2: Minichromosome maintenance protein 2; MMP: Matrix metalloproteinase; MTs: Metallothioneins; NCBI: National Center of Biotechnology Information; NF-kB: Nuclear factor-kB; NPS: Nanoparticles; PDGF: Platelet-derived growth factor; PI3K: Phosphatidylinositol 3-kinase; pRNA: Packaging RNA; rPOA: Reducible poly(oligo-D-arginine); shMT: Short hairpin RNAs against MTs; siRNA: Short interfering RNA; SMCs: Smooth muscle cells; SNP: Single nucleotide polymorphism; TGCTs: Testicular germ cell tumors; TGF 1 : Transforming growth factor $\beta 1$; TNM: Tumor node metastasis; tPSA: Total prostate-specific antigen; VEGF: Vascular endothelial growth factor

\section{Authors' contributions}

$\mathrm{LJH}$ was responsible for the conception and design of the manuscript. SMF was a major contributor in writing the manuscript. Both authors read and approved the final manuscript.

\section{Authors' information}

LJH is an expert on gynecological oncology at the Chinese Academy of Engineering and the head of the Department of Obstetrics and Gynecology, Peking Union Medical College Hospital, Peking Union Medical College, Chinese Academy of Medical Sciences, No. 1 Shuaifuyuan, Dongcheng District, Beijing 100730, China.

\section{Ethics approval and consent to participate}

Not applicable.

\section{Consent for publication}

Not applicable.

\section{Competing interests}

The authors declare that they have no competing interests.

\section{Publisher's Note}

Springer Nature remains neutral with regard to jurisdictional claims in published maps and institutional affiliations.

Received: 17 April 2018 Accepted: 1 August 2018

Published online: 23 August 2018

\section{References}

1. Coyle P, Philcox JC, Carey LC, Rofe AM. Metallothionein: the multipurpose protein. Cell Mol Life Sci. 2002;59:627-47.

2. Albrecht AL, Singh RK, Somji S, Sens MA, Sens DA, Garrett SH. Basal and metal-induced expression of metallothionein isoform 1 and 2 genes in the RWPE-1 human prostate epithelial cell line. J Appl Toxicol. 2008;28:283-93.

3. Margoshes M, Vallee BL. A cadmium protein from equine kidney cortex. J Am Chem Soc. 1957;79:4813-4.

4. Klaassen CD, Liu J, Diwan BA. Metallothionein protection of cadmium toxicity. Toxicol Appl Pharmacol. 2009:238:215-20.

5. Kumari MV, Hiramatsu M, Ebadi M. Free radical scavenging actions of metallothionein isoforms I and II. Free Radic Res. 1998;29:93-101.

6. Arriaga JM, Levy EM, Bravo Al, Bayo SM, Amat M, Aris M, Hannois A, Bruno L, Roberti MP, Loria FS, et al. Metallothionein expression in colorectal cancer: relevance of different isoforms for tumor progression and patient survival. Hum Pathol. 2012;43:197-208.

7. Ferrario C, Lavagni P, Gariboldi M, Miranda C, Losa M, Cleris L, Formelli F, Pilotti S, Pierotti MA, Greco A. Metallothionein $1 \mathrm{G}$ acts as an oncosupressor in papillary thyroid carcinoma. Lab Investig. 2008:88:474-81.

8. Zheng Y, Jiang L, Hu Y, Xiao C, Xu N, Zhou J, Zhou X. Metallothionein $1 \mathrm{H}$ (MT1H) functions as a tumor suppressor in hepatocellular carcinoma through regulating Wnt/beta-catenin signaling pathway. BMC Cancer. 2017;17:161.
9. Pedersen MO, Larsen A, Stoltenberg M, Penkowa M. The role of metallothionein in oncogenesis and cancer prognosis. Prog Histochem Cytochem. 2009;44:29-64.

10. Demidenko R, Daniunaite K, Bakavicius A, Sabaliauskaite R, Skeberdyte A, Petroska D, Laurinavicius A, Jankevicius F, Lazutka JR, Jarmalaite S. Decreased expression of MT1E is a potential biomarker of prostate cancer progression. Oncotarget. 2017:8:61709-18.

11. Vasak M. Advances in metallothionein structure and functions. J Trace Elem Med Biol. 2005:19:13-7.

12. Thirumoorthy N, Manisenthil Kumar KT, Shyam Sundar A, Panayappan L, Chatterjee M. Metallothionein: an overview. World J Gastroenterol. 2007;13:993-6.

13. Moleirinho A, Carneiro J, Matthiesen R, Silva RM, Amorim A, Azevedo L. Gains, losses and changes of function after gene duplication: study of the metallothionein family. PLoS One. 2011;6:e18487.

14. Krzeslak A, Forma E, Chwatko G, Jozwiak P, Szymczyk A, Wilkosz J, Rozanski $W$, Brys M. Effect of metallothionein 2A gene polymorphism on allelespecific gene expression and metal content in prostate cancer. Toxicol Appl Pharmacol. 2013;268:278-85.

15. Ruttkay-Nedecky B, Nejdl L, Gumulec J, Zitka O, Masarik M, Eckschlager T, Stiborova M, Adam V, Kizek R. The role of metallothionein in oxidative stress. Int J Mol Sci. 2013;14:6044-66.

16. Krezel A, Maret $\mathbf{W}$. The functions of metamorphic metallothioneins in zinc and copper metabolism. Int J Mol Sci. 2017;18(6). https://doi.org/10.3390/ ijms18061237.

17. Cherian MG, Jayasurya A, Bay BH. Metallothioneins in human tumors and potential roles in carcinogenesis. Mutat Res. 2003;533:201-9.

18. Shimoda R, Achanzar WE, Qu W, Nagamine T, Takagi H, Mori M, Waalkes MP. Metallothionein is a potential negative regulator of apoptosis. Toxicol Sci. 2003;73:294-300.

19. Dutsch-Wicherek M, Sikora J, Tomaszewska R. The possible biological role of metallothionein in apoptosis. Front Biosci. 2008;13:4029-38.

20. Gomulkiewicz A, Podhorska-Okolow M, Szulc R, Smorag Z, Wojnar A, Zabel $M$, Dziegiel P. Correlation between metallothionein (MT) expression and selected prognostic factors in ductal breast cancers. Folia Histochem Cytobiol. 2010;48:242-8.

21. Jayasurya A, Bay BH, Yap WM, Tan NG, Tan BK. Proliferative potential in nasopharyngeal carcinoma: correlations with metallothionein expression and tissue zinc levels. Carcinogenesis. 2000:21:1809-12.

22. Hengstler JG, Pilch H, Schmidt M, Dahlenburg H, Sagemuller J, Schiffer I, Oesch F, Knapstein PG, Kaina B, Tanner B. Metallothionein expression in ovarian cancer in relation to histopathological parameters and molecular markers of prognosis. Int J Cancer. 2001;95:121-7.

23. Wulfing $\mathrm{C}$, van Ahlen $\mathrm{H}$, Eltze $\mathrm{E}$, Piechota $\mathrm{H}$, Hertle L, Schmid KW. Metallothionein in bladder cancer: correlation of overexpression with poor outcome after chemotherapy. World J Urol. 2007;25:199-205.

24. Weinlich G, Eisendle K, Hassler E, Baltaci M, Fritsch PO, Zelger B. Metallothionein - overexpression as a highly significant prognostic factor in melanoma: a prospective study on 1270 patients. Br J Cancer. 2006;94:835-41.

25. Datta J, Majumder S, Kutay H, Motiwala T, Frankel W, Costa R, Cha HC, MacDougald OA, Jacob ST, Ghoshal K. Metallothionein expression is suppressed in primary human hepatocellular carcinomas and is mediated through inactivation of CCAAT/enhancer binding protein alpha by phosphatidylinositol 3-kinase signaling cascade. Cancer Res. 2007;67:2736-46.

26. Han YC, Zheng ZL, Zuo ZH, Yu YP, Chen R, Tseng GC, Nelson JB, Luo JH. Metallothionein $1 \mathrm{~h}$ tumour suppressor activity in prostate cancer is mediated by euchromatin methyltransferase 1. J Pathol. 2013;230:184-93.

27. Theocharis S, Karkantaris C, Philipides T, Agapitos E, Gika A, Margeli A, Kittas C, Koutselinis A. Expression of metallothionein in lung carcinoma: correlation with histological type and grade. Histopathology. 2002;40:143-51.

28. Lee JD, Wu SM, Lu LY, Yang YT, Jeng SY. Cadmium concentration and metallothionein expression in prostate cancer and benign prostatic hyperplasia of humans. J Formos Med Assoc. 2009;108:554-9.

29. Dziegiel P, Pula B, Kobierzycki C, Stasiolek M, Podhorska-Okolow M: The role of metallothioneins in carcinogenesis. Metallothioneins in Normal and Cancer Cells 2016, 218:29-63.

30. Uchida $Y$, Takio $K$, Titani $K$, Ihara $Y$, Tomonaga $M$. The growth inhibitory factor that is deficient in the Alzheimer's disease brain is a 68 amino acid metallothionein-like protein. Neuron. 1991:7:337-47.

31. Palmiter RD, Findley SD, Whitmore TE, Durnam DM. MT-III, a brainspecific member of the metallothionein gene family. Proc Natl Acad Sci U S A. 1992;89:6333-7. 
32. Quaife CJ, Findley SD, Erickson JC, Froelick GJ, Kelly EJ, Zambrowicz BP, Palmiter RD. Induction of a new metallothionein isoform (MT-IV) occurs during differentiation of stratified squamous epithelia. Biochemistry. 1994;33:7250-9.

33. Haq F, Mahoney M, Koropatnick J. Signaling events for metallothionein induction. Mutat Res. 2003:533:211-26.

34. Krizkova S, Kepinska M, Emri G, Eckschlager T, Stiborova M, Pokorna P, Heger Z, Adam V. An insight into the complex roles of metallothioneins in malignant diseases with emphasis on (sub)isoforms/isoforms and epigenetics phenomena. Pharmacol Ther. 2018;183:90-117.

35. Cherian MG, Huang PC, Klaassen CD, Liu YP, Longfellow DG, Waalkes MP. National Cancer Institute Workshop on the possible roles of metallothionein in carcinogenesis. Cancer Res. 1993;53:922-5.

36. Nagel WW, Vallee BL. Cell cycle regulation of metallothionein in human colonic cancer cells. Proc Natl Acad Sci U S A. 1995;92:579-83.

37. Chesters JK, Petrie L, Vint $H$. Specificity and timing of the $\mathrm{Zn} 2+$ requirement for DNA synthesis by 3T3 cells. Exp Cell Res. 1989;184:499-508.

38. Chesters JK, Boyne R. Nature of the Zn2+ requirement for DNA synthesis by 3T3 cells. Exp Cell Res. 1991;192:631-4.

39. Lim D, Jocelyn KM, Yip GW, Bay BH. Silencing the metallothionein-2A gene inhibits cell cycle progression from G1- to S-phase involving ATM and cdc25A signaling in breast cancer cells. Cancer Lett. 2009;276:109-17.

40. Werynska B, Pula B, Muszczynska-Bernhard B, Piotrowska A, Jethon A, Podhorska-Okolow M, Dziegiel P, Jankowska R. Correlation between expression of metallothionein and expression of Ki-67 and MCM-2 proliferation markers in non-small cell lung cancer. Anticancer Res. 2011;31:2833-9.

41. Jin RX, Chow VTK, Tan PH, Dheen ST, Duan W, Bay BH. Metallothionein 2A expression is associated with cell proliferation in breast cancer. Carcinogenesis. 2002;23:81-6.

42. Dziegiel P, Forgacz J, Suder E, Surowiak P, Kornafel J, Zabel M. Prognostic significance of metallothionein expression in correlation with Ki-67 expression in adenocarcinomas of large intestine. Histol Histopathol. 2003;18:401-7.

43. Bieniek A, Pula B, Piotrowska A, Podhorska-Okolow M, Salwa A, Koziol M, Dziegiel P. Expression of metallothionein I/II and Ki-67 antigen in various histological types of basal cell carcinoma. Folia Histochem Cytobiol. 2012;50:352-7.

44. Dziegiel P, Salwa-Zurawska W, Zurawski J, Wojnar A, Zabel M. Prognostic significance of augmented metallothionein (MT) expression correlated with Ki-67 antigen expression in selected soft tissue sarcomas. Histol Histopathol. 2005;20:83-9.

45. Alkamal I, Ikromov O, Tolle A, Fuller TF, Magheli A, Miller K, Krause H, Kempkensteffen C. An epigenetic screen unmasks metallothioneins as putative contributors to renal cell carcinogenesis. Urol Int. 2015;94:99-110.

46. Ostrakhovitch EA, Olsson PE, Jiang S, Cherian MG. Interaction of metallothionein with tumor suppressor p53 protein. FEBS Lett. 2006;580:1235-8.

47. Abdel-Mageed AB, Agrawal KC. Activation of nuclear factor kappaB: potential role in metallothionein-mediated mitogenic response. Cancer Res. 1998:58:2335-8

48. Sakurai A, Hara S, Okano N, Kondo Y, Inoue J, Imura N. Regulatory role of metallothionein in NF-kappaB activation. FEBS Lett. 1999;455:55-8.

49. Marikar FM, Jin G, Sheng W, Ma D, Hua Z. Metallothionein $2 A$ an interactive protein linking phosphorylated FADD to NF-kappaB pathway leads to colorectal cancer formation. Chin Clin Oncol. 2016;5:76.

50. Klaassen CD, Liu J, Choudhuri S. Metallothionein: an intracellular protein to protect against cadmium toxicity. Annu Rev Pharmacol Toxicol. 1999:39:267-94.

51. Wang GW, Klein JB, Kang YJ. Metallothionein inhibits doxorubicin-induced mitochondrial cytochrome $c$ release and caspase-3 activation in cardiomyocytes. J Pharmacol Exp Ther. 2001;298:461-8.

52. Yan DW, Fan JW, Yu ZH, Li MX, Wen YG, Li DW, Zhou CZ, Wang XL, Wang $\mathrm{Q}$, Tang HM, Peng ZH. Downregulation of metallothionein $1 F$, a putative oncosuppressor, by loss of heterozygosity in colon cancer tissue. Biochim Biophys Acta. 1822;2012:918-26.

53. Dutta R, Sens DA, Somji S, Sens MA, Garrett SH. Metallothionein isoform 3 expression inhibits cell growth and increases drug resistance of PC-3 prostate cancer cells. Prostate. 2002;52:89-97.

54. Aikins AR, Hong SW, Kim HJ, Yoon CH, Chung JH, Kim MJ, Kim CW. Extremely low-frequency electromagnetic field induces neural differentiation of hBM-MSCs through regulation of (Zn)-metallothionein-3. Bioelectromagnetics. 2017;38:364-73.

55. Wu C, Pot C, Apetoh L, Thalhamer T, Zhu B, Murugaiyan G, Xiao S, Lee Y, Rangachari M, Yosef N, Kuchroo VK. Metallothioneins negatively regulate IL-27-induced type 1 regulatory T-cell differentiation. Proc Natl Acad Sci U S A. 2013;110:7802-7.

56. Hirako N, Nakano H, Takahashi S. A PU.1 suppressive target gene, metallothionein 1G, inhibits retinoic acid-induced NB4 cell differentiation. PLoS One. 2014;9:e103282.

57. Habel N, Hamidouche Z, Girault I, Patino-Garcia A, Lecanda F, Marie PJ, Fromigue O. Zinc chelation: a metallothionein 2A's mechanism of action involved in osteosarcoma cell death and chemotherapy resistance. Cell Death Dis. 2013;4:e874.

58. Jin R, Bay BH, Chow VT, Tan PH. Metallothionein 1F mRNA expression correlates with histological grade in breast carcinoma. Breast Cancer Res Treat. 2001;66:265-72.

59. Yap XL, Tan HY, Huang JX, Lai YY, Yip GWC, Tan PH, Bay BH. Overexpression of metallothionein predicts chemoresistance in breast cancer. J Pathol. 2009;217:563-70.

60. Gallicchio LM, Flaws JA, Fowler BA, loffe OB. Metallothionein expression in invasive and in situ breast carcinomas. Cancer Detect Prev. 2005;29:332-7.

61. Rezk NA, Zidan HE, Riad M, Mansy W, Mohamad SA. Metallothionein 2A expression and its relation to different clinical stages and grades of breast cancer in Egyptian patients. Gene. 2015;571:17-22.

62. Ohshio G, Imamura T, Okada N, Wang ZH, Yamaki K, Kyogoku T, Suwa H, Yamabe H, Imamura M. Immunohistochemical study of metallothionein in pancreatic carcinomas. J Cancer Res Clin Oncol. 1996;122:351-5.

63. Shukla VK, Aryya NC, Pitale A, Pandey M, Dixit VK, Reddy CD, Gautam A. Metallothionein expression in carcinoma of the gallbladder. Histopathology. 1998;33:154-7.

64. Izawa Jl, Moussa M, Cherian MG, Doig G, Chin JL. Metallothionein expression in renal cancer. Urology. 1998;52:767-72.

65. McCluggage WG, Strand K, Abdulkadir A. Immunohistochemical localization of metallothionein in benign and malignant epithelial ovarian tumors. Int J Gynecol Cancer. 2002;12:62-5.

66. McCluggage WG, Maxwell P, Hamilton PW, Jasani B. High metallothionein expression is associated with features predictive of aggressive behaviour in endometrial carcinoma. Histopathology. 1999;34:51-5.

67. Arriaga JM, Bravo Al, Mordoh J, Bianchini M. Metallothionein $1 \mathrm{G}$ promotes the differentiation of HT-29 human colorectal cancer cells. Oncol Rep. 2017;37:2633-51.

68. Eichhorn ME, Kleespies A, Angele MK, Jauch KW, Bruns CJ. Angiogenesis in cancer: molecular mechanisms, clinical impact. Langenbecks Arch Surg. 2007:392:371-9.

69. Miyashita H, Sato Y. Metallothionein 1 is a downstream target of vascular endothelial zinc finger 1 (VEZF1) in endothelial cells and participates in the regulation of angiogenesis. Endothelium. 2005;12:163-70.

70. Penkowa M, Carrasco J, Giralt M, Molinero A, Hernandez J, Campbell IL, Hidalgo J. Altered central nervous system cytokine-growth factor expression profiles and angiogenesis in metallothionein-I+II deficient mice. J Cereb Blood Flow Metab. 2000;20:1174-89.

71. Wierzowiecka B, Gomulkiewicz A, Cwynar-Zajac L, Olbromski M, Grzegrzolka J, Kobierzycki C, Podhorska-Okolow M, Dziegiel P. Expression of metallothionein and vascular endothelial growth factor isoforms in breast cancer cells. In Vivo. 2016;30:271-8.

72. Kim HG, Hwang YP, Jeong HG. Metallothionein-III induces HIF-1 alphamediated VEGF expression in brain endothelial cells. Biochem Biophys Res Commun. 2008;369:666-71.

73. Schuermann A, Helker CSM, Herzog W. Metallothionein 2 regulates endothelial cell migration through transcriptional regulation of vegfc expression. Angiogenesis. 2015;18:463-75.

74. Farina AR, Mackay AR. Gelatinase B/MMP-9 in tumour pathogenesis and progression. Cancers. 2014;6:240-96.

75. Zalewska M, Trefon J, Milnerowicz H. The role of metallothionein interactions with other proteins. Proteomics. 2014;14:1343-56.

76. Zbinden S, Wang JS, Adenika R, Schmidt M, Tilan JU, Najafi AH, Peng $X Z$, Lassance-Soares RM, lantorno M, Morsli H, et al. Metallothionein enhances angiogenesis and arteriogenesis by modulating smooth muscle cell and macrophage function. Arterioscler Thromb Vasc Bio. 2010:30:477-U240.

77. Emri E, Egervari K, Varvolgyi T, Rozsa D, Miko E, Dezso B, Veres I, Mehes G, Emri G, Remenyik E. Correlation among metallothionein expression, intratumoural macrophage infiltration and the risk of metastasis in human cutaneous malignant melanoma. J Eur Acad Dermatol Venereol. 2013;27:e320-7. 
78. Hishikawa Y, Kohno H, Ueda S, Kimoto T, Dhar DK, Kubota H, Tachibana M, Koji T, Nagasue N. Expression of metallothionein in colorectal cancers and synchronous liver metastases. Oncology. 2001;61:162-7.

79. Haerslev T, Jacobsen K, Nedergaard L, Zedeler K. Immunohistochemical detection of metallothionein in primary breast carcinomas and their axillary lymph node metastases. Pathol Res Pract. 1994;190:675-81.

80. Hishikawa Y, Koji T, Dhar DK, Kinugasa S, Yamaguchi M, Nagasue N. Metallothionein expression correlates with metastatic and proliferative potential in squamous cell carcinoma of the oesophagus. Br J Cancer. 1999;81:712-20.

81. Galizia G, Ferraraccio F, Lieto E, Orditura M, Castellano P, Imperatore V, La Manna G, Pinto M, Ciardiello F, La Mura A, De Vita F. p27 downregulation and metallothionein overexpression in gastric cancer patients are associated with a poor survival rate. J Surg Oncol. 2006;93:241-52.

82. Kim HG, Kim JY, Han EH, Hwang YP, Choi JH, Park BH, Jeong HG. Metallothionein$2 \mathrm{~A}$ overexpression increases the expression of matrix metalloproteinase-9 and invasion of breast cancer cells. FEBS Lett. 2011;585:421-8.

83. Kmiecik AM, Pula B, Suchanski J, Olbromski M, Gomulkiewicz A, Owczarek T, Kruczak A, Ambicka A, Rys J, Ugorski M, et al. Metallothionein-3 increases triple-negative breast cancer cell invasiveness via induction of metalloproteinase expression. PLoS One. 2015;10:e0124865.

84. Hur H, Ryu HH, Li CH, Kim IY, Jang WY, Jung S. Metallothinein 1E enhances glioma invasion through modulation matrix metalloproteinases-2 and 9 in U87MG mouse brain tumor model. J Korean Neurosurg Soc. 2016;59:551-8.

85. Ryu HH, Jung S, Jung TY, Moon KS, Kim IY, Jeong YI, Jin SG, Pei J, Wen M, Jang WY. Role of metallothionein $1 \mathrm{E}$ in the migration and invasion of human glioma cell lines. Int J Oncol. 2012;41:1305-13.

86. Ramaswamy S, Ross KN, Lander ES, Golub TR. A molecular signature of metastasis in primary solid tumors. Nat Genet. 2003;33:49-54.

87. Giorgi RR, Correa-Giannella MLC, Casarini APM, Machado MC, Bronstein MD, Cescato VA, Giannella-Neto D. Metallothionein isoform 3 gene is differentially expressed in corticotropin-producing pituitary adenomas. Neuroendocrinology. 2005;82:208-14.

88. Gomulkiewicz A, Jablonska K, Pula B, Grzegrzolka J, Borska S, PodhorskaOkolow M, Wojnar A, Rys J, Ambicka A, Ugorski M, et al. Expression of metallothionein 3 in ductal breast cancer. Int J Oncol. 2016;49:2487-97.

89. Fu J, Lv H, Guan H, Ma X, Ji M, He N, Shi B, Hou P. Metallothionein $1 \mathrm{G}$ functions as a tumor suppressor in thyroid cancer through modulating the PI3K/Akt signaling pathway. BMC Cancer. 2013;13:462.

90. Dutsch-Wicherek M, Lazar A, Tomaszewska R. The potential role of MT and vimentin immunoreactivity in the remodeling of the microenvironment of parotid adenocarcinoma. Cancer Microenviron. 2010;4:105-13.

91. Dutsch-Wicherek M, Lazar A, Tomaszewska R, Kazmierczak W, Wicherek $L$. Analysis of metallothionein and vimentin immunoreactivity in pharyngeal squamous cell carcinoma and its microenvironment. Cell Tissue Res. 2013:352:341-9.

92. Dutsch-Wicherek M. RCAS1, MT, and vimentin as potential markers of tumor microenvironment remodeling. Am J Reprod Immunol. 2010;63:181-8.

93. Subramanian Vignesh K, Deepe GS Jr. Metallothioneins: emerging modulators in immunity and infection. Int J Mol Sci. 2017;18(10). https://doi. org/10.3390/ijms18102197.

94. Popiela TJ, Rudnicka-Sosin L, Dutsch-Wicherek M, Klimek M, Basta P, Galazka $K$, Wicherek L. The metallothionein and RCAS1 expression analysis in breast cancer and adjacent tissue regarding the immune cells presence and their activity. Neuroendocrinol Lett. 2006;27:786-94.

95. Borghesi LA, Youn J, Olson EA, Lynes MA. Interactions of metallothionein with murine lymphocytes: plasma membrane binding and proliferation. Toxicology. 1996;108:129-40.

96. Youn J, Lynes MA. Metallothionein-induced suppression of cytotoxic T lymphocyte function: an important immunoregulatory control. Toxicol Sci. 1999;52:199-208.

97. Canpolat $\mathrm{E}$, Lynes MA. In vivo manipulation of endogenous metallothionein with a monoclonal antibody enhances a T-dependent humoral immune response. Toxicol Sci. 2001;62:61-70.

98. Kelley SL, Basu A, Teicher BA, Hacker MP, Hamer DH, Lazo JS. Overexpression of metallothionein confers resistance to anticancer drugs. Science. 1988;241:1813-5.

99. Siegsmund MJ, Marx C, Seemann O, Schummer B, Steidler A, Toktomambetova L, Kohrmann KU, Rassweiler J, Alken P. Cisplatinresistant bladder carcinoma cells: enhanced expression of metallothioneins. Urol Res. 1999;27:157-63.

100. Matsumoto Y, Oka M, Sakamoto A, Narasaki F, Fukuda M, Takatani H, Terashi K, Ikeda K, Tsurutani J, Nagashima S, et al. Enhanced expression of metallothionein in human non-small-cell lung carcinomas following chemotherapy. Anticancer Res. 1997:17:3777-80.

101. Kasahara K, Fujiwara Y, Nishio K, Ohmori T, Sugimoto Y, Komiya K, Matsuda T, Saijo N. Metallothionein content correlates with the sensitivity of human small cell lung cancer cell lines to cisplatin. Cancer Res. 1991;51:3237-42.

102. Lee JH, Chae JW, Kim JK, Kim HJ, Chung JY, Kim YH. Inhibition of cisplatinresistance by RNA interference targeting metallothionein using reducible oligo-peptoplex. J Control Release. 2015;215:82-90.

103. Chun JH, Kim HK, Kim E, Kim IH, Kim JH, Chang HJ, Choi IJ, Lim HS, Kim IJ, Kang $\mathrm{HC}$, et al. Increased expression of metallothionein is associated with irinotecan resistance in gastric cancer. Cancer Res. 2004;64:4703-6.

104. Juang $\mathrm{HH}$, Chung LC, Sung HC, Feng $\mathrm{TH}$, Lee $\mathrm{YH}$, Chang PL, Tsui KH. Metallothionein 3: an androgen-upregulated gene enhances cell invasion and tumorigenesis of prostate carcinoma cells. Prostate. 2013;73:1495-506.

105. Kondo Y, Kuo SM, Watkins SC, Lazo JS. Metallothionein localization and cisplatin resistance in human hormone-independent prostatic tumor cell lines. Cancer Res. 1995;55:474-7.

106. Surowiak P, Materna V, Maciejczyk A, Pudelko M, Markwitz E, Spaczynski M, Dietel M, Zabel M, Lage H. Nuclear metallothionein expression correlates with cisplatin resistance of ovarian cancer cells and poor clinical outcome. Virchows Arch. 2007:450:279-85.

107. Gansukh T, Donizy P, Halon A, Lage H, Surowiak P. In vitro analysis of the relationships between metallothionein expression and cisplatin sensitivity of non-small cellular lung cancer cells. Anticancer Res. 2013;33:5255-60.

108. Arriaga JM, Greco A, Mordoh J, Bianchini M. Metallothionein $1 \mathrm{G}$ and zinc sensitize human colorectal cancer cells to chemotherapy. Mol Cancer Ther. 2014;13:1369-81.

109. Sun XF, Niu XH, Chen RC, He WY, Chen D, Kang R, Tang DL. Metallothionein$1 \mathrm{G}$ facilitates sorafenib resistance through inhibition of ferroptosis. Hepatology. 2016:64:488-500.

110. Shuai Y, Guo JB, Peng SQ, Zhang LS, Guo J, Han G, Dong YS. Metallothionein protects against doxorubicin-induced cardiomyopathy through inhibition of superoxide generation and related nitrosative impairment. Toxicol Lett. 2007;170:66-74.

111. Heger Z, Rodrigo MAM, Krizkova S, Ruttkay-Nedecky B, Zalewska M, del Pozo EMP, Pelfrene A, Pourrut B, Stiborova M, Eckschlager T, et al. Metallothionein as a scavenger of free radicals - new cardioprotective therapeutic agent or initiator of tumor chemoresistance? Curr Drug Targets. 2016;17:1438-51.

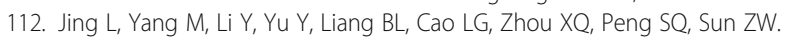
Metallothionein prevents doxorubicin cardiac toxicity by indirectly regulating the uncoupling proteins 2. Food Chem Toxicol. 2017;110:204-13.

113. Petrlova J, Potesil D, Mikelova R, Blastik O, Adam V, Trnkova L, Jelen F, Prusa R, Kukacka J, Kizek R. Attomole voltammetric determination of metallothionein. Electrochim Acta. 2006;51:5112-9.

114. Eckschlager T, Adam V, Hrabeta J, Figova K, Kizek R. Metallothioneins and cancer. Curr Protein Pept Sci. 2009;10:360-75.

115. Tariba B, Zivkovic T, Krasnici N, Marijic VF, Erk M, Gamulin M, Grgic M, Pizent A. Serum metallothionein in patients with testicular cancer. Cancer Chemother Pharmacol. 2015;75:813-20.

116. Krizkova S, Ryvolova M, Gumulec J, Masarik M, Adam V, Majzlik P, Hubalek J, Provaznik I, Kizek R. Electrophoretic fingerprint metallothionein analysis as a potential prostate cancer biomarker. Electrophoresis. 2011;32:1952-61.

117. Krizkova S, Masarik M, Majzlik P, Kukacka J, Kruseova J, Adam V, Prusa R, Eckschlager T, Stiborova M, Kizek R. Serum metallothionein in newly diagnosed patients with childhood solid tumours. Acta Biochim Pol. 2010;57:561-6.

118. Surowiak P, Materna V, Kaplenko I, Spaczynski M, Dietel M, Lage H, Zabel M. Augmented expression of metallothionein and glutathione S-transferase pi as unfavourable prognostic factors in cisplatin-treated ovarian cancer patients. Virchows Arch. 2005;447:626-33.

119. Jin RX, Huang JX, Tan PH, Bay BH. Clinicopathological significance of metallothioneins in breast cancer. Pathol Oncol Res. 2004;10:74-9.

120. Goulding H, Jasani B, Pereira H, Reid A, Galea M, Bell JA, Elston CW, Robertson JF, Blamey RW, Nicholson RA, et al. Metallothionein expression in human breast cancer. Br J Cancer. 1995;72:968-72.

121. Joseph MG, Banerjee D, Kocha W, Feld R, Stitt LW, Cherian MG. Metallothionein expression in patients with small cell carcinoma of the lung: correlation with other molecular markers and clinical outcome. Cancer. 2001:92:836-42.

122. Dziegiel $P$, Jelen M, Muszczynska B, Maciejczyk A, Szulc A, PodhorskaOkolow M, Cegielski M, Zabel M. Role of metallothionein expression in nonsmall cell lung carcinomas. Rocz Akad Med Bialymst. 2004;49(Suppl 1):43-5. 
123. Tuzel E, Kirkali Z, Yorukoglu K, Mungan MU, Sade M. Metallothionein expression in renal cell carcinoma: subcellular localization and prognostic significance. J Urol. 2001;165:1710-3.

124. Mitropoulos D, Kyroudi-Voulgari A, Theocharis S, Serafetinides E, Moraitis E, Zervas A, Kittas C. Prognostic significance of metallothionein expression in renal cell carcinoma. World J Surg Oncol. 2005;3:5.

125. Weinlich G, Bitterlich W, Mayr V, Fritsch PO, Zelger B. Metallothioneinoverexpression as a prognostic factor for progression and survival in melanoma A prospective study on 520 patients. Br J Dermatol. 2003;149:535-41.

126. Yamasaki Y, Smith C, Weisz D, van Huizen I, Xuan J, Moussa M, Stitt L, Hideki $\mathrm{S}$, Cherian MG, Izawa J. Metallothionein expression as prognostic factor for transitional cell carcinoma of bladder. Urology. 2006;67:530-5.

127. Cardoso SV, Barbosa HM, Candellori IM, Loyola AM, Aguiar MC. Prognostic impact of metallothionein on oral squamous cell carcinoma. Virchows Arch. 2002:441:174-8.

128. Schmitz KJ, Lang H, Kaiser G, Wohlschlaeger J, Sotiropoulos GC, Baba HA, Jasani B, Schmid KW. Metallothionein overexpression and its prognostic relevance in intrahepatic cholangiocarcinoma and extrahepatic hilar cholangiocarcinoma (Klatskin tumors). Hum Pathol. 2009:40:1706-14.

129. Zhang $R$, Zhang $H$, Wei $H$, Luo X. Expression of metallothionein in invasive ductal breast cancer in relation to prognosis. J Environ Pathol Toxicol Oncol. 2000;19:95-7.

130. Sens MA, Somji S, Garrett SH, Beall CL, Sens DA. Metallothionein isoform 3 overexpression is associated with breast cancers having a poor prognosis. Am J Pathol. 2001;159:21-6.

131. Werynska B, Pula B, Muszczynska-Bernhard B, Gomulkiewicz A, Piotrowska A, Prus R, Podhorska-Okolow M, Jankowska R, Dziegiel P. Metallothionein 1F and 2A overexpression predicts poor outcome of non-small cell lung cancer patients. Exp Mol Pathol. 2013;94:301-8.

132. Weinlich G, Topar G, Eisendle K, Fritsch PO, Zelger B. Comparison of metallothionein-overexpression with sentinel lymph node biopsy as prognostic factors in melanoma. J Eur Acad Dermatol Venereol. 2007;21:669-77.

133. Park Y, Yu E. Expression of metallothionein-1 and metallothionein-2 as a prognostic marker in hepatocellular carcinoma. J Gastroenterol Hepatol. 2013;28:1565-72

134. Ding J, Lu SC. Low metallothionein $1 \mathrm{M}$ expression association with poor hepatocellular carcinoma prognosis after curative resection. Genet Mol Res. 2016;15(4). https://doi.org/10.4238/gmr.15048735.

135. Pan Y, Huang J, Xing R, Yin X, Cui J, Li W, Yu J, Lu Y. Metallothionein 2A inhibits NF-kappaB pathway activation and predicts clinical outcome segregated with TNM stage in gastric cancer patients following radical resection. J Transl Med. 2013;11:173.

136. Ji XF, Fan YC, Gao S, Yang Y, Zhang JJ, Wang K. MT1M and MT1G promoter methylation as biomarkers for hepatocellular carcinoma. World J Gastroenterol. 2014;20:4723-9.

137. Meplan C, Richard MJ, Hainaut P. Metalloregulation of the tumor suppressor protein p53: zinc mediates the renaturation of p53 after exposure to metal chelators in vitro and in intact cells. Oncogene. 2000;19:5227-36.

138. Ostrakhovitch EA, Olsson PE, von Hofsten J, Cherian MG. P53 mediated regulation of metallothionein transcription in breast cancer cells. J Cell Biochem. 2007;102:1571-83.

139. Cardoso SV, Silveira-Junior JB, De Carvalho MV, De-Paula AM, Loyola AM, De Aguiar MC. Expression of metallothionein and p53 antigens are correlated in oral squamous cell carcinoma. Anticancer Res. 2009;29:1189-93.

140. Fan LZ, Cherian MG. Potential role of p53 on metallothionein induction in human epithelial breast cancer cells. Br J Cancer. 2002;87:1019-26.

141. Ioachim EE, Kitsiou E, Carassavoglou C, Stefanaki S, Agnantis NJ. Immunohistochemical localization of metallothionein in endometrial lesions. J Pathol. 2000;191:269-73.

142. Mao J, Yu HX, Wang CJ, Sun LH, Jiang W, Zhang PZ, Xiao QY, Han DB, Saiyin $\mathrm{H}$, Zhu JD, et al. Metallothionein MT1M is a tumor suppressor of human hepatocellular carcinomas. Carcinogenesis. 2012;33:2568-77.

143. Tse KY, Liu WW, Chan DW, Chiu PM, Tam KF, Chan KK, Liao XY, Cheung AN, Ngan HY. Epigenetic alteration of the metallothionein $1 E$ gene in human endometrial carcinomas. Tumour Biol. 2009;30:93-9.

144. Faller WJ, Rafferty M, Hegarty S, Gremel G, Ryan D, Fraga MF, Esteller M, Dervan PA, Gallagher WM. Metallothionein $1 \mathrm{E}$ is methylated in malignant melanoma and increases sensitivity to cisplatin-induced apoptosis. Melanoma Res. 2010;20:392-400.

145. Roth MJ, Abnet CC, Hu N, Wang QH, Wei WQ, Green L, D'Alelio M, Qiao YL, Dawsey SM, Taylor PR, Woodson K. p16, MGMT, RARbeta2, CLDN3, CRBP and MT1G gene methylation in esophageal squamous cell carcinoma and its precursor lesions. Oncol Rep. 2006;15:1591-7.

146. Kumar A, Chatopadhyay T, Raziuddin M, Ralhan R. Discovery of deregulation of zinc homeostasis and its associated genes in esophageal squamous cell carcinoma using cDNA microarray. Int J Cancer. 2007;120:230-42.

147. Sakamoto LH, DEC B, Cajaiba M, Soares FA, Vettore AL. MT1G hypermethylation: a potential prognostic marker for hepatoblastoma. Pediatr Res. 2010;67:387-93.

148. Kanda M, Nomoto S, Okamura Y, Nishikawa Y, Sugimoto H, Kanazumi N, Takeda S, Nakao A. Detection of metallothionein $1 \mathrm{G}$ as a methylated tumor suppressor gene in human hepatocellular carcinoma using a novel method of double combination array analysis. Int J Oncol. 2009;35:477-83.

149. Huang $Y$, de la Chapelle A, Pellegata NS. Hypermethylation, but not $L O H$, is associated with the low expression of MT1G and CRABP1 in papillary thyroid carcinoma. Int J Cancer. 2003;104:735-44.

150. Henrique R, Jeronimo C, Hoque MO, Nomoto S, Carvalho AL, Costa VL, Oliveira J, Teixeira MR, Lopes C, Sidransky D. MT1G hypermethylation is associated with higher tumor stage in prostate cancer. Cancer Epidemiol Biomark Prev. 2005;14:1274-8.

151. Deng D, El-Rifai W, Ji J, Zhu B, Trampont P, Li J, Smith MF, Powel SM. Hypermethylation of metallothionein-3 CpG island in gastric carcinoma. Carcinogenesis. 2003;24:25-9.

152. Peng DF, Hu TL, Jiang AX, Washington MK, Moskaluk CA, Schneider-Stock R, El-Rifai W. Location-specific epigenetic regulation of the metallothionein 3 gene in esophageal adenocarcinomas. PLoS One. 2011;6(7):e22009.

153. Smith E, Drew PA, Tian ZQ, De Young NJ, Liu JF, Mayne GC, Ruszkiewicz AR, Watson $\mathrm{DI}$, Jamieson GG. Metallothionien 3 expression is frequently downregulated in oesophageal squamous cell carcinoma by DNA methylation. Mol Cancer. 2005;4. https://doi.org/10.1186/1476-4598-4-42.

154. Tao YF, Xu LX, Lu J, Cao L, Li ZH, Hu SY, Wang NN, Du XJ, Sun LC, Zhao WL, et al. Metallothionein III (MT3) is a putative tumor suppressor gene that is frequently inactivated in pediatric acute myeloid leukemia by promoter hypermethylation. J Transl Med. 2014;12:182.

155. Chan KYY, Lai PBS, Squire JA, Beheshti B, Wong NLY, Sy SMH, Wong N. Positional expression profiling indicates candidate genes in deletion hotspots of hepatocellular carcinoma. Mod Pathol. 2006;19:1546-54.

156. Inoue $\mathrm{K}$, Satoh M. Metallothionein as a therapeutic molecular target against human diseases. Curr Pharm Biotechnol. 2013;14:391-3.

157. Ito $Y$, Tanaka $H$, Hara $H$. The potential roles of metallothionein as a therapeutic target for cerebral ischemia and retinal diseases. Curr Pharm Biotechnol. 2013;14:400-7

158. Fujiwara $Y$, Satoh M. Protective role of metallothionein in chemical and radiation carcinogenesis. Curr Pharm Biotechnol. 2013;14:394-9.

159. Guo S, Huang F, Guo P. Construction of folate-conjugated pRNA of bacteriophage phi29 DNA packaging motor for delivery of chimeric siRNA to nasopharyngeal carcinoma cells. Gene Ther. 2006;13:814-20.

160. Guo S, Tschammer N, Mohammed S, Guo P. Specific delivery of therapeutic RNAs to cancer cells via the dimerization mechanism of phi29 motor pRNA. Hum Gene Ther. 2005;16:1097-109.

161. Tarapore P, Shu Y, Guo P, Ho SM. Application of phi29 motor pRNA for targeted therapeutic delivery of siRNA silencing metallothionein-IIA and survivin in ovarian cancers. Mol Ther. 2011;19:386-94.

162. Overholtzer M, Mailleux AA, Mouneimne G, Normand G, Schnitt SJ, King RW Cibas ES, Brugge JS. A nonapoptotic cell death process, entosis, that occurs by cell-in-cell invasion. Cell. 2007;131:966-79.

163. Lai Y, Lim D, Tan PH, Leung TK, Yip GW, Bay BH. Silencing the metallothionein-2A gene induces entosis in adherent MCF-7 breast cancer cells. Anat Rec (Hoboken). 2010;293:1685-91.

164. Krizkova S, Ryvolova M, Hrabeta J, Adam V, Stiborova M, Eckschlager T, Kizek R. Metallothioneins and zinc in cancer diagnosis and therapy. Drug Metab Rev. 2012:44:287-301.

165. Abdel-Mageed A, Agrawal KC. Antisense down-regulation of metallothionein induces growth arrest and apoptosis in human breast carcinoma cells. Cancer Gene Ther. 1997;4:199-207.

166. Takeda A, Hisada H, Okada S, Mata JE, Ebadi M, Iversen PL. Tumor cell growth is inhibited by suppressing metallothionein-I synthesis. Cancer Lett. 1997;116:145-9.

167. Tan OJ, Bay BH, Chow VT. Differential expression of metallothionein isoforms in nasopharyngeal cancer and inhibition of cell growth by antisense downregulation of metallothionein-2A. Oncol Rep. 2005;13:127-31.

168. Sharma S, Rais A, Sandhu R, Nel W, Ebadi M. Clinical significance of metallothioneins in cell therapy and nanomedicine. Int Nanomedicine. 2013;8:1477-88. 
169. Penkowa M. Metallothioneins are multipurpose neuroprotectants during brain pathology. FEBS J. 2006;273:1857-70.

170. Levadoux-Martin M, Hesketh JE, Beattie JH, Wallace HM. Influence of metallothionein-1 localization on its function. Biochem J. 2001;355:473-9.

171. Karin M, Eddy RL, Henry WM, Haley LL, Byers MG, Shows TB. Human metallothionein genes are clustered on chromosome 16. Proc Natl Acad Sci U S A. 1984;81:5494-8.

172. West AK, Stallings R, Hildebrand CE, Chiu R, Karin M, Richards RI. Human metallothionein genes: structure of the functional locus at 16q13. Genomics. 1990;8:513-8.

173. Heguy A, West A, Richards RI, Karin M. Structure and tissue-specific expression of the human metallothionein IB gene. Mol Cell Biol. 1986;6:2149-57.

174. Varshney U, Jahroudi N, Foster R, Gedamu L. Structure, organization, and regulation of human metallothionein IF gene: differential and cell-typespecific expression in response to heavy metals and glucocorticoids. Mol Cell Biol. 1986;6:26-37.

175. Foster R, Jahroudi N, Varshney U, Gedamu L. Structure and expression of the human metallothionein-IG gene. Differential promoter activity of two linked metallothionein-I genes in response to heavy metals. J Biol Chem. 1988;263:11528-35.

176. Stennard FA, Holloway AF, Hamilton J, West AK. Characterisation of six additional human metallothionein genes. Biochim Biophys Acta. 1994;1218:357-65.

177. Cai X, Wang J, Huang X, Fu W, Xia W, Zou M, Wang Y, Wang J, Xu D. Identification and characterization of MT-1X as a novel FHL3-binding partner. PLoS ONE [Electronic Resource]. 2014;9:e93723.

178. Karin M, Richards RI. Human metallothionein genes--primary structure of the metallothionein-Il gene and a related processed gene. Nature. 1982;299:797-802.

179. Yamazaki S, Nakanishi M, Hamamoto T, Hirata H, Ebihara A, Tokue A, Kagawa Y. Expression of human metallothionein-Il fusion protein in Escherichia coli. Biochem Int. 1992;28:451-60.

180. Vasak M, Meloni G. Mammalian metallothionein-3: new functional and structura insights. Int J Mol Sci. 2017;18(6):1117. https://doi.org/10.3390/ijms18061117.

181. Chen HI, Chiu YW, Hsu YK, Li WF, Chen YC, Chuang HY. The association of metallothionein-4 gene polymorphism and renal function in long-term lead-exposed workers. Biol Trace Elem Res. 2010;137:55-62.

182. Sauerbrey A, Zintl F, Hermann J, Volm M. Multiple resistance mechanisms in acute nonlymphoblastic leukemia (ANLL). Anticancer Res. 1998;18:1231-6.

183. Imoto A, Okada M, Okazaki T, Kitasato H, Harigae H, Takahashi S. Metallothionein-1 isoforms and vimentin are direct PU.1 downstream target genes in leukemia cells. J Biol Chem. 2010;285:10300-9.

184. Alves SM, Cardoso SV, de Fatima BV, Machado VC, Mesquita RA, Vieira do Carmo MA, Ferreira Aguiar MC. Metallothionein immunostaining in adenoid cystic carcinomas of the salivary glands. Oral Oncol. 2007;43:252-6.

185. Rossen K, Haerslev T, Hou-Jensen K, Jacobsen GK. Metallothionein expression in basaloid proliferations overlying dermatofibromas and in basal cell carcinomas. Br J Dermatol. 1997;136:30-4.

186. Pula B, Tazbierski T, Zamirska A, Werynska B, Bieniek A, Szepietowski J, Rys J, Dziegiel P, Podhorska-Okolow M. Metallothionein 3 expression in normal skin and malignant skin lesions. Pathol Oncol Res. 2015;21:187-93.

187. Slusser A, Zheng Y, Zhou XD, Somji S, Sens DA, Sens MA, Garrett SH. Metallothionein isoform 3 expression in human skin, related cancers and human skin derived cell cultures. Toxicol Lett. 2015;232:141-8.

188. Saika T, Tsushima T, Ochi J, Akebi N, Nasu Y, Matsumura Y, Ohmori H. Over-expression of metallothionein and drug-resistance in bladder cancer. Int J Urol. 1994;1:135-9.

189. Sens MA, Somji S, Lamm DL, Garrett SH, Slovinsky F, Todd JH, Sens DA. Metallothionein isoform 3 as a potential biomarker for human bladder cancer. Environ Health Perspect. 2000;108:413-8.

190. Somji S, Sens MA, Lamm DL, Garrett SH, Sens DA. Metallothionein isoform 1 and 2 gene expression in the human bladder: evidence for upregulation of MT-1X mRNA in bladder cancer. Cancer Detect Prev. 2001;25:62-75.

191. Tai SK, Tan OJ, Chow VT, Jin R, Jones JL, Tan PH, Jayasurya A, Bay BH. Differential expression of metallothionein 1 and 2 isoforms in breast cancer lines with different invasive potential: identification of a novel nonsilent metallothionein-1H mutant variant. Am J Pathol. 2003;163:2009-19.

192. Jansova E, Koutna I, Krontorad P, Svoboda Z, Krivankova S, Zaloudik J, Kozubek M, Kozubek S. Comparative transcriptome maps: a new approach to the diagnosis of colorectal carcinoma patients using cDNA microarrays. Clin Genet. 2006;69:218-27.

193. Jin R, Bay BH, Chow VTK, Tan PH, Lin VCL. Metallothionein $1 E$ mRNA is highly expressed in oestrogen receptor-negative human invasive ductal breast cancer. Br J Cancer. 2000;83:319-23.
194. Hishikawa Y, Abe S, Kinugasa S, Yoshimura H, Monden N, Igarashi M, Tachibana M, Nagasue N. Overexpression of metallothionein correlates with chemoresistance to cisplatin and prognosis in esophageal cancer. Oncology. 1997;54:342-7.

195. Oka D, Yamashita S, Tomioka T, Nakanishi Y, Kato H, Kaminishi M, Ushijima $T$. The presence of aberrant DNA methylation in noncancerous esophageal mucosae in association with smoking history a target for risk diagnosis and prevention of esophageal cancers. Cancer. 2009;115:3412-26.

196. Suganuma K, Kubota T, Saikawa Y, Abe S, Otani Y, Furukawa T, Kumai K, Hasegawa H, Watanabe M, Kitajima $M$, et al. Possible chemoresistance-related genes for gastric cancer detected by cDNA microarray. Cancer Sci. 2003;94:355-9.

197. An J, Pan Y, Yan Z, Li W, Cui J, Yuan J, Tian L, Xing R, Lu Y. MiR-23a in amplified 19p13.13 loci targets metallothionein 2A and promotes growth in gastric cancer cells. J Cell Biochem. 2013;114:2160-9.

198. Lin ZH, Lai SC, Zhuo W, Chen SJ, Si JM, Wang L. Gastric cancer related IncRNA-MTM involved in cell migration and invasion by interacting with MT1F. Gastroenterology. 2016;150:\$359.

199. Yang J, Zhang YB, Liu P, Yan HL, Ma JC, Da MX. Decreased expression of long noncoding RNA MT1.JP may be a novel diagnostic and predictive biomarker in gastric cancer. Int J Clin Exp Pathol. 2017;10:432-8.

200. Lu DD, Chen YC, Zhang XR, Cao XR, Jiang HY, Yao L. The relationship between metallothionein-1F (MT1F) gene and hepatocellular carcinoma. Yale J Biol Med. 2003;76:55-62.

201. Tao X, Zheng JM, Xu AM, Chen XF, Zhang SH. Downregulated expression of metallothionein and its clinicopathological significance in hepatocellular carcinoma. Hepatol Res. 2007;37:820-7.

202. Li H, Lu YF, Chen H, Liu J. Dysregulation of metallothionein and circadian genes in human hepatocellular carcinoma. Chronobiol Int. 2017;34:192-202.

203. Fu CL, Pan B, Pan JH, Gan MF. Metallothionein $1 \mathrm{M}$ suppresses tumorigenesis in hepatocellular carcinoma. Oncotarget. 2017;8:33037-46.

204. Subrungruang I, Thawornkuno C, Chawalitchewinkoon-Petmitr P, Pairojkul C, Wongkham S, Petmitr S. Gene expression profiling of intrahepatic cholangiocarcinoma. Asian Pac J Cancer Prev. 2013;14:557-63.

205. Liang GY, Lu SX, Xu G, Liu XD, Li J, Zhang DS. Expression of metallothionein and Nrf2 pathway genes in lung cancer and cancer-surrounding tissues. World J Surg Oncol. 2013;11:199.

206. da Motta LL, De Bastiani MA, Stapenhorst F, Klamt F. Oxidative stress associates with aggressiveness in lung large-cell carcinoma. Tumour Biol. 2015:36:4681-8.

207. Hou XF, Fan QX, Wang LX, Lu SX. Role of metallothionein1h in cisplatin resistance of non-small cell lung cancer cells. Chin J Cancer Res. 2009;21:247-54.

208. Werynska B, Pula B, Muszczynska-Bernhard B, Gomulkiewicz A, Jethon A, Podhorska-Okolow M, Jankowska R, Dziegiel P. Expression of metallothionein-III in patients with non-small cell lung cancer. Anticancer Res. 2013;33:965-74.

209. Brazao-Silva MT, Rodrigues MF, Eisenberg AL, Dias FL, de Castro LM, Nunes FD, Faria PR, Cardoso SV, Loyola AM, de Sousa SC. Metallothionein gene expression is altered in oral cancer and may predict metastasis and patient outcomes. Histopathology. 2015;67:358-67.

210. Endo-Munoz L, Cumming A, Sommerville S, Dickinson I, Saunders NA Osteosarcoma is characterised by reduced expression of markers of osteoclastogenesis and antigen presentation compared with normal bone. Br J Cancer. 2010;103:73-81.

211. Tekur S, Ho SM. Ribozyme-mediated downregulation of human metallothionein II(a) induces apoptosis in human prostate and ovarian cancer cell lines. Mol Carcinog. 2002;33:44-55.

212. Mougeot JLC, Bahrani-Mostafavi Z, Vachris JC, McKinney KQ, Gurlov S, Zhang J, Naumann RW, Higgins RV, Hall JB. Gene expression profiling of ovarian tissues for determination of molecular pathways reflective of tumorigenesis. J Mol Biol. 2006;358:310-29.

213. Garrett SH, Sens MA, Shukla D, Nestor S, Somji S, Todd JH, Sens DA Metallothionein isoform 3 expression in the human prostate and cancerderived cell lines. Prostate. 1999:41:196-202

214. Garrett SH, Sens MA, Shukla D, Flores L, Somji S, Todd JH, Sens DA. Metallothionein isoform 1 and 2 gene expression in the human prostate: downregulation of MT-1X in advanced prostate cancer. Prostate. 2000;43:125-35.

215. Prueitt RL, Yi M, Hudson RS, Wallace TA, Howe TM, Yfantis HG, Lee DH, Stephens RM, Liu CG, Calin GA, et al. Expression of microRNAs and proteincoding genes associated with perineural invasion in prostate cancer. Prostate. 2008;68:1152-64. 
216. Nguyen A, Jing Z, Mahoney PS, Davis R, Sikka SC, Agrawal KC, AbdelMageed $A B$. In vivo gene expression profile analysis of metallothionein in renal cell carcinoma. Cancer Lett. 2000;160:133-40.

217. Takahashi M, Rhodes DR, Furge KA, Kanayama H, Kagawa S, Haab BB, Teh BT. Gene expression profiling of clear cell renal cell carcinoma: gene identification and prognostic classification. Proc Natl Acad Sci U S A. 2001;98:9754-9.

218. Tan $Y$, Sinniah R, Bay BH, Singh G. Metallothionein expression and nuclear size in benign, borderline, and malignant serous ovarian tumours. J Pathol. 1999;189:60-5.

219. Skubitz KM, Francis P, Skubitz APN, Luo XH, Nilbert M. Gene expression identifies heterogeneity of metastatic propensity in high-grade soft tissue sarcomas. Cancer. 2012;118:4235-43.

220. Sundelin K, Jadner M, Norberg-Spaak L, Davidsson A, Hellquist HB, Metallothionein and Fas (CD95) are expressed in squamous cell carcinoma of the tongue. Eur J Cancer. 1997;33:1860-4.

221. Theocharis S, Klijanienko J, Giaginis C, Rodriquez J, Jouffroy T, Girod A, Point $D$, Tsourouflis G, Sastre-Garau X. Metallothionein expression in mobile tongue squamous cell carcinoma: associations with clinicopathological parameters and patient survival. Histopathology. 2011;59:514-25.

222. Chin JL, Banerjee D, Kadhim SA, Kontozoglou TE, Chauvin PJ, Cherian MG. Metallothionein in testicular germ cell tumors and drug resistance. Clinical correlation. Cancer. 1993;72:3029-35.

Ready to submit your research? Choose BMC and benefit from:

- fast, convenient online submission

- thorough peer review by experienced researchers in your field

- rapid publication on acceptance

- support for research data, including large and complex data types

- gold Open Access which fosters wider collaboration and increased citations

- maximum visibility for your research: over $100 \mathrm{M}$ website views per year

At $\mathrm{BMC}$, research is always in progress.

Learn more biomedcentral.com/submissions 